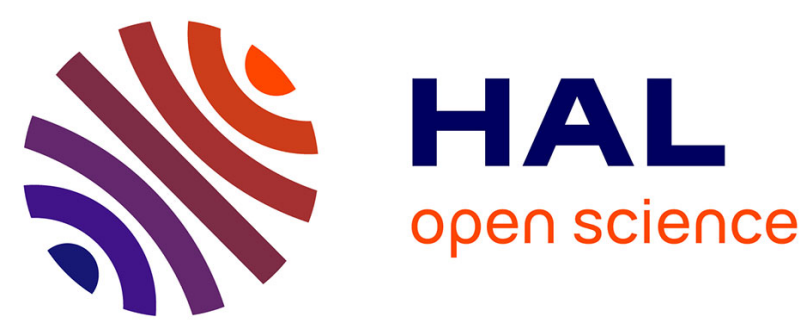

\title{
Vema Fracture Zone (central Atlantic): Tectonic and Magmatic Evolution of the Median Ridge and the Eastern Ridge-Transform Intersection Domain
}

Yves Lagabrielle, Vassilios Mamaloukas-Frangoulis, Mathilde Cannat, Jean-Marie Auzende, Jose Honnorez, Catherine Mevel, Enrico Bonatrl

\section{To cite this version:}

Yves Lagabrielle, Vassilios Mamaloukas-Frangoulis, Mathilde Cannat, Jean-Marie Auzende, Jose Honnorez, et al.. Vema Fracture Zone (central Atlantic): Tectonic and Magmatic Evolution of the Median Ridge and the Eastern Ridge-Transform Intersection Domain. Journal of Geophysical Research, 1992, 97 (B12), pp.331-348. 10.1029/92JB01086 . insu-01894655

\section{HAL Id: insu-01894655 \\ https://hal-insu.archives-ouvertes.fr/insu-01894655}

Submitted on 12 Oct 2018

HAL is a multi-disciplinary open access archive for the deposit and dissemination of scientific research documents, whether they are published or not. The documents may come from teaching and research institutions in France or abroad, or from public or private research centers.
L'archive ouverte pluridisciplinaire HAL, est destinée au dépôt et à la diffusion de documents scientifiques de niveau recherche, publiés ou non, émanant des établissements d'enseignement et de recherche français ou étrangers, des laboratoires publics ou privés. 


\title{
Vema Fracture Zone (Central Atlantic): Tectonic and Magmatic Evolution of the Median Ridge and the Eastern Ridge-Transform Intersection Domain
}

\author{
YVES LAGABRIELLE, ${ }^{1}$ VASSILIOS MAMALOUKAS-FRANGOULIS, ${ }^{1}$ MATHIIDE CANNAT, ${ }^{2}$ \\ JEAN-MARIE AUZENDE, ${ }^{3}$ JOSE HONNOREZ, ${ }^{4}$ CATHERINE MEVEL, 5 \\ ANDENRICO BONATTI 6
}

\begin{abstract}
The eastem Vema fracture zone intersection with the Mid-Atlantic Ridge (MAR) axis was surveyed with the French submersible Nautile during the Vemanaute cruise in 1989. At this ridge-transform intersection (RTI), an elongated, E-W ridge, more than $50 \mathrm{~km}$ long, is present in the transform valley. This median ridge rises up to $1000 \mathrm{~m}$ above the surrounding seafloor. The crest of the median ridge is lower and presents an arcuate shape at the tip of the MAR axis. Dive observations on both the southem and northem flanks of the median ridge as well as sample studies suggest that this morphological feature is not a serpentinized mantle protrusion or a recent volcanic constructional ridge but represents a sliver of uplifted oceanic lithosphere covered by a sedimentary breccia formation. This detrital cover consists of polymictic sedimentary breccias, sandstones and siltstones, composed of basaltic, doleritic, and gabbroic clasts, with less frequent serpentinite and spinel fragments which originated from the disaggregation of shallow to deep levels of tectonically uplifted oceanic crust and upper mantle. Most of these clasts have undergone greenschist facies metamorphism prior to their incorporation in the detrital formation. Disaggregation, mass wasting and rapid emplacement of detrital formations on the valley floor by gravity flows are likely to be related to a major tectonic episode that affected one or both the fracture valley walls. This event could be related to the uplift of the southem wall of the fracture zone (the "transverse ridge") which took place probably between 10 and $3 \mathrm{Ma}$ ago. Since this uplift episode, the transverse ridge (which is now undergoing subsidence) and the detritus covered transform valley floor, separated by the transform fault zone, have migrated westward and eastward respectively. Vertical tectonics of the median ridge at the approach of the RTI can not be explained solely by the hypothesis of a diapiric intrusion of serpentinite as proposed by earlier authors. A possible interpretation follows the suggestions that the anomalous crust of the fracture valley near the westem RTI, is more than $1 \mathrm{~km}$ out of isostatic equilibrium. Recent tectonic and magmatic events including subsidence and lava emplacement which occurred at the tip of the MAR axis have been recorded on the southern flank of the median ridge. Several stages in the very recent tectonic-volcanic history of the eastem RTI, that is, roughly during the last 300,000 years, can thus be defined. The lower elevation and narrow, arcuate shape of the median ridge east of $40^{\circ} 57^{\prime} \mathrm{W}$ are inferred to have resulted from tectonic extension during the creation of the nodal basin.
\end{abstract}

\section{INTRODUCTION}

Ridge axis/transform fault intersections (RTIs) are wide areas where an accreting plate boundary intersects a boundary along which lithosphere is theoretically neither created nor destroyed. RTI domains are the sites of complex interactions between magmatic and tectonic processes related to seafloor spreading and to transform faulting, respectively [Sleep and

\footnotetext{
${ }^{1}$ Centre National de la Recherche Scientifique, Unité de Recherche Associée: Domaines Océaniques, Université de Bretagne Occidentale, Brest, France.

${ }^{2}$ Centre National de la Recherche Scientifique, Unité de Recherche Associée: Domaines Océaniques, Université de Bretagne Occidentale, Brest, France; now at Laboratoire de Pétrologie Métamorphique, Université Pierre et Marie Curie, Paris, France.

${ }^{3}$ Institut Français de Recherche pour l'Exploitation de la Mer,

Département Géosciences Marines, Centre de Brest, France.

${ }^{4}$ Institut de Géologie, Université Louis Pasteur, Strasbourg, France.

${ }^{5}$ Centre National de la Recherche Scientifique, Laboratoire de Pétrologie Métamorphique, Université Pierre et Marie Curie, Paris, France.

6 I amont-Doherty Geological Observatory of Columbia University, Palisades, New York, USA.

Copyright 1992 by the American Geophysical Union.

Paper number 92JB01086.

0148-0227/92/92JB-01086\$05.00
}

Biehler, 1970]. The best known of the intersections between the Mid-Atlantic Ridge (MAR) axis and its major fracture zones (offset greater than $30 \mathrm{~km}$ ) are both RTIs of the Kane fracture zone (FZ), and the eastern RTIs of both the Oceanographer and Vema fracture zones. All of these RTIs have been the targets of conventional bathymetric surveys, geophysical studies, Seabeam mapping and diving cruises [Karson and Dick, 1983; Fox and Gallo, 1984; Oceanographer Tectonic Research (OTTER) Team, 1984; Williams et al., 1984; Macdonald et al., 1986; Pockalny et al., 1988; Mével et al., 1989].

Atlantic RTIs often display comparable morphological features. The MAR axis broadens and deepens when approaching the transform fault. In the intersection domain, it plunges into a circular or triangular-shaped depression, the nodal basin. The depth of nodal basins varies from $5000 \mathrm{~m}$ up to more than $6000 \mathrm{~m}$, at the Kane eastern RTI. One or several neovolcanic constructional ridges crosscut the floor of some nodal basins, indicating recent propagation of magmatic activity into the intersection domain.

Despite such morphological similarities, the Atlantic RTIs exhibit different geological characteristics suggesting various stages in their tectonic or magmatic evolution. Dredging results as well as direct sampling during submersible dives indicate that a great variety of rocks are exposed in the nodal basins. The Vema eastem nodal basin is floored with fresh basaltic lavas only, while gabbros and serpentinites have been 


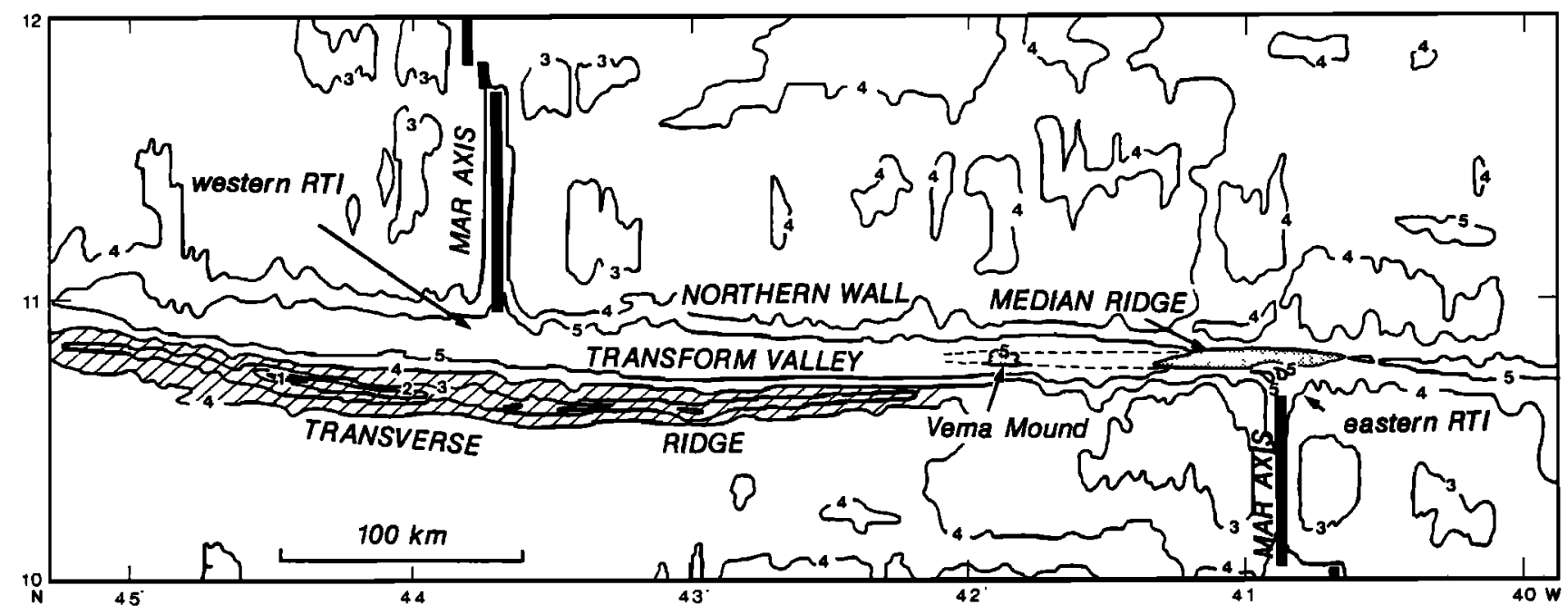

Fig. 1. Schematic bathymetric map of the Vema fracture zone. Hatched area emphasizes the transverse ridge; shaded area emphasizes the median ridge and its western extension, the "Vema mound".

sampled in the Kane and Oceanographer RTIs, respectively, showing that deep crustal levels as well as mantle rocks may be exposed at RTIs. A number of models accounting for the topographic and geological characteristics of the best studied RTIs have been proposed [Karson and Dick, 1983; Fox and Gallo; 1984, Mével et al., 1991]. All of them emphasize that a combination of altemating periods of magmatic construction and tectonic stretching is responsible for their peculiar patterns. The authors generally conclude that tectonic processes are dominant in the lithosphere exposed at nodal basins of RTIs with respect to magmatic processes.

Topographic features such as ridges located in the transform valley are found only in some RTIs. In particular, the Vema eastern RTI domain is characterized by the presence of a transform parallel topographic feature, the median ridge, that bisects the transform valley east of $41^{\circ} 30^{\prime} \mathrm{W}$ (Figure 1) rising up to $1000 \mathrm{~m}$ above the valley floor. Similar ridges have been described in other major Atlantic fracture zones (Gibbs FZ [Olivet et al., 1974; Searle, 1981]; Romanche FZ [Bonatti et al., 1974; Bonatii and Honnorez, 1976]; Doldrums FZ (Mazarovich et al., unpublished)), but the ridges may also be reduced (Kane FZ [Pockalny et al., 1988]) or totally missing (Oceanographer FZ [OTTER Team, 1985]). Prominent median ridges have also been mapped in some fracture zones of the Indian Ocean (Atlantis II FZ [Dick et al., 1991]), and the Pacific (Clipperton FZ [Gallo et al., 1986]; Tamayo FZ [Kastens et al., 1979; Macdonald et al., 1979]). Little is known about the geology and the deep structure of these median ridges. Despite a scarcity of direct geological data, median ridges have been interpreted by most authors as resulting from the diapiric rise of serpentinized upper mantle in the transform valley [Macdonald et al., 1986]. Median ridges, however, are not universally present, and are usually not continuous along the entire length of the transform. Moreover, previous dredging or drilling results from median ridges have revealed that they do not consist exclusively of ultramafic rocks. Rocks dredged at about $41^{\circ} 00 \mathrm{~W}, 10^{\circ} 45 \mathrm{~N}$ along the southem flank of the Vema median ridge include undeformed and cataclastic basalt fragments [Mével, 1981] and sedimentary basaltic breccias. Gabbro, basalt and volcaniclastic material in addition to peridotites were dredged from the northern slope of the Vema mound, the western extension of the Vema median ridge at about $41^{\circ} 50^{\prime}$ (E. Bonatti, unpublished data, 1984). Dredge hauls collected from the median ridge of the Romanche $F Z$ at $18^{\circ} 12^{\prime} \mathrm{W}, 0^{\circ} 10^{\prime} \mathrm{S}$ consisted of all the usual oceanic basic and ultrabasic rocks and their metamorphic equivalents and hydrothermal pyrite concretions [Bonatti and Honnorez, 1976]. The Atlantis II FZ median ridge (southwest Indian Ocean) was dredged, drilled, and explored with a towed televiewer during Ocean Drilling Program (ODP) leg 118, and during the preliminary survey cruise [Robinson et al., 1989; Dick et al., 1991]. It appears to have a thick cover of sand and gravel, and occasional large blocks of gabbro, basalts, serpentinized peridotites, and amphibolites.

A geological study of the Vema FZ was carried out in 1988 , during the Vemanaute cruise by the French submersible Nautile. Two zones were surveyed: the first one is located along the southern wall of the fracture zone where a section including mantle serpentinites, gabbros, sheeted dykes and basaltic pillows has been observed and sampled [Auzende et al., 1988; Cannat et al., 1991]; the second one corresponds to the eastern RTI domain. This paper follows two previous papers [Auzende et al., 1989; Mamaloukas-Frangoulis et al., 1991] where dive observations on the morphological expression of the transform activity at the eastern RTI and on the nature of the nodal basin and neovolcanic ridge are presented.

In this paper, we present additional data obtained from submersible observations across the Vema transform median ridge, between $41^{\circ} \mathrm{W}$ and the RTI nodal basin (Figures 1,2 and 4) and petrological information. Based on these observations, we propose interpretations regarding the geology of the Vema median ridge, and we discuss (1) the origin of the median ridge; (2) the possible causes of its uplift as one approaches the RTI (3) a simple model of the very recent magmatic and tectonic evolution of the median ridge-MAR axis junction.

\section{Main STRUCTURAL UNITS OF THE VEMa FRACTURE ZONE}

The Vema FZ, located near $11^{\circ} \mathrm{N}$ latitude, is the northernmost of a set of major equatorial transform faults that offset the MAR. The total offset along the Vema FZ is $320 \mathrm{~km}$ (Figure 1). Given a slip rate of $32 \mathrm{~mm} / \mathrm{yr}$ [Cande et al., 1988], 


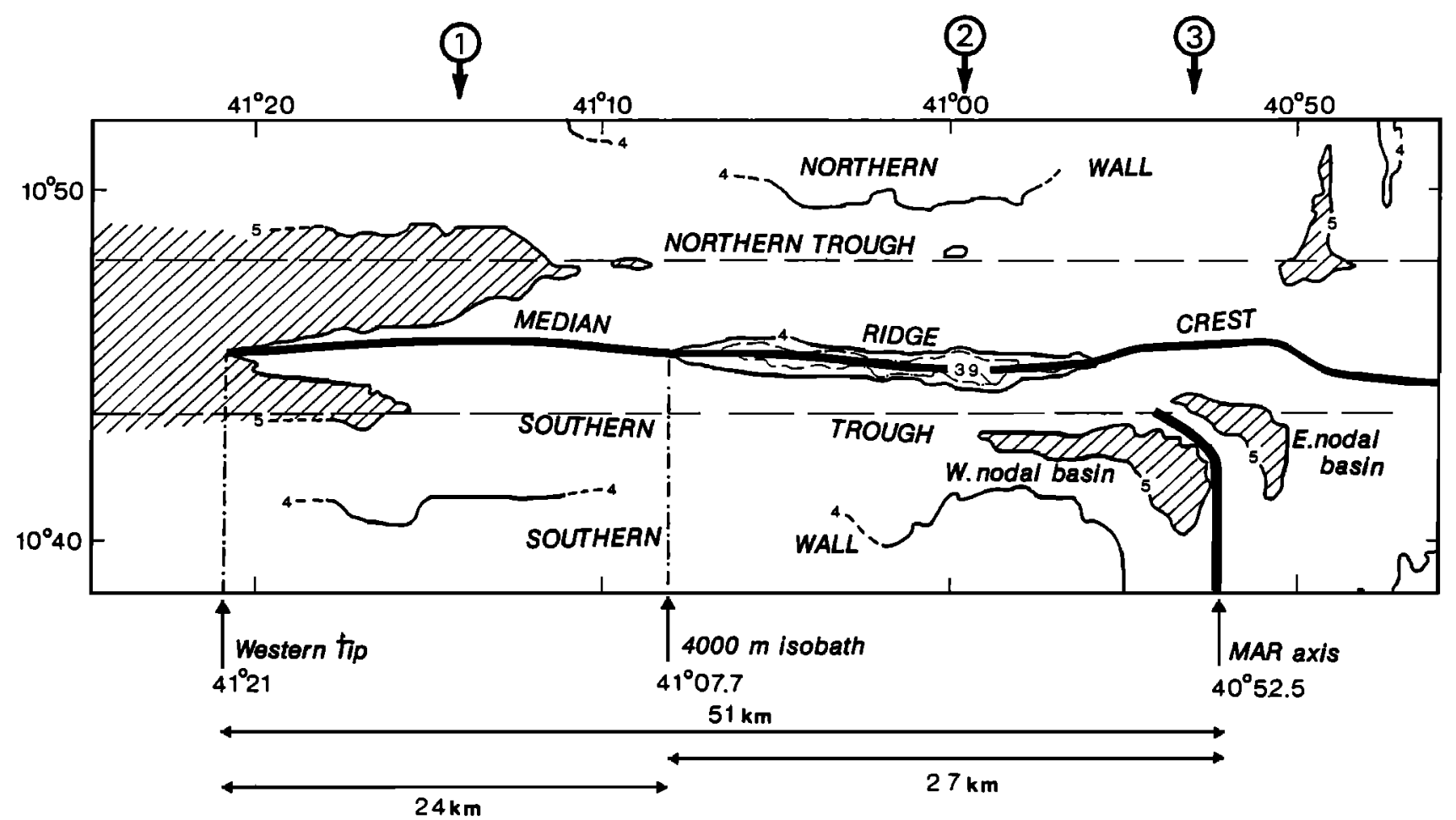

Fig. 2. Main morphometric features of the Vema median ridge. Hatched areas represent zones deeper than $5 \mathrm{~km}$. Note that the higher portion of the median ridge is not located at the tip of the MAR axis. Depth in kilometers.

the age of the oceanic crust facing each MAR axis is about 20 Ma. The active segment of the fracture zone is marked by a $5100 \mathrm{~m}$ deep and $15-20 \mathrm{~km}$ wide, flat-floored valley bounded by two walls. The valley is filled with late Tertiary turbidites originating from the Amazon cone, which have been emplaced across the Demerara abyssal plain [Van Andel et al.,1967; 1971; Bader et al., 1970; Perch-Nielsen et al., 1977; Kastens et al., 1986]. This turbiditic infill is much thicker in the western part of the transform valley and is up to $1.5 \mathrm{~km}$ thick at the western RTI [Eittreim and Ewing, 1975; Bowen and White, 1986]. By contrast, the eastern RTI has a very thin to absent pelagic cover [Macdonald et al., 1986; Kastens et al., 1986; Auzende et al., 1989]. A narrow zone of disturbed sediments identified on seismic lines recorded by Eittreim and Ewing [1975] and interpreted as the trace of the transform fault, connects the western and eastem intersection basins.

The southem wall of the transform valley is defined by a major topographic feature, the transverse ridge (Figure 1), which culminates at $600 \mathrm{~m}$ below sea level along the western inactive segment of the fracture zone [Van Andel et al., 1967, 1971]. This ridge constitutes a major topographic anomaly relative to the predicted depth-age relationship. Geophysical data, dredged sample studies and submersible observations have shown that the transverse ridge can be interpreted as an uplifted and tilted section of mature oceanic crust [Thompson and Melson, 1972; Prinz et al., 1976; Bonatti and Honnorez, 1976; Ludwig and Rabinowitz, 1980; Honnorez et al., 1984, Louden et al., 1986; Auzende et al., 1989; Cannat et al., 1991]. Paleontological and stable isotope data from dredged limestones indicate that its summit was above sea level from 10 to $3 \mathrm{Ma}$ and subsequently sank to its present position at a rate of about $0.3 \mathrm{~mm} / \mathrm{yr}$ [Honnorez et al., 1975; Bonatti and Crane, 1982; Bonatti et al., 1983]. Although numerous processes accounting for the creation of the ridge have been proposed, including volume increase due to serpentinization of upper mantle rocks, changes in plate motion and related oscillatory spreading, and thermal effects due to spreading axis intersection, its origin remains controversial.

Seismic profiles indicate the presence in the transform valley of one or more partially buried basement highs [Eittreim and Ewing, 1975; Bowen and White, 1986; Kastens et al., 1986]. Due to the lack of accurate data, it remains unclear whether the buried basement highs observed in the westem half of the transform fault are part of a continuous elongated feature. A basement high emerges locally from the sedimentary infill of the valley floor at $41^{\circ} 50^{\prime}$ forming the Vema mound (Figure 1). The basement emerges again in the easternmost part of the active segment. It forms a continuous ridge, the median ridge, running parallel to the valley axis and culminating at about $1000 \mathrm{~m}$ above the valley floor (Figures 2 and 3 ).

The 3.5-kHz reflection records obtained near the eastern RTI at about $41^{\circ} 30^{\prime}$ (profile B in Figure 5 of Eittreim and Ewing [1975]) show that the flat floor of the valley located to the north of the transform fault zone is uplifted. This is consistent with the interpretation of Deep Tow's $4-\mathrm{kHz}$ seismic profiles suggesting that the western tip of the median ridge has undergone recent, i.e., Pleistocene, uplift at a rate possibly as high as $1 \mathrm{~mm} / \mathrm{yr}$ [Kastens et al., 1986].

Available geophysical data on the Vema FZ concern only the western portion of the transform valley (west of the Vema mound; Figure 1). There is unfortunately no constraint on the crustal structure of the eastem part of the transform fault and more particularly on the deep structure of the median ridge. Seismic experiments [Ludwig and Rabinowitz, 1980; Detrick et al., 1982; Louden et al., 1986] indicate that the crust in the western part of the transform valley is 4 to $5 \mathrm{~km}$ thick, and is 

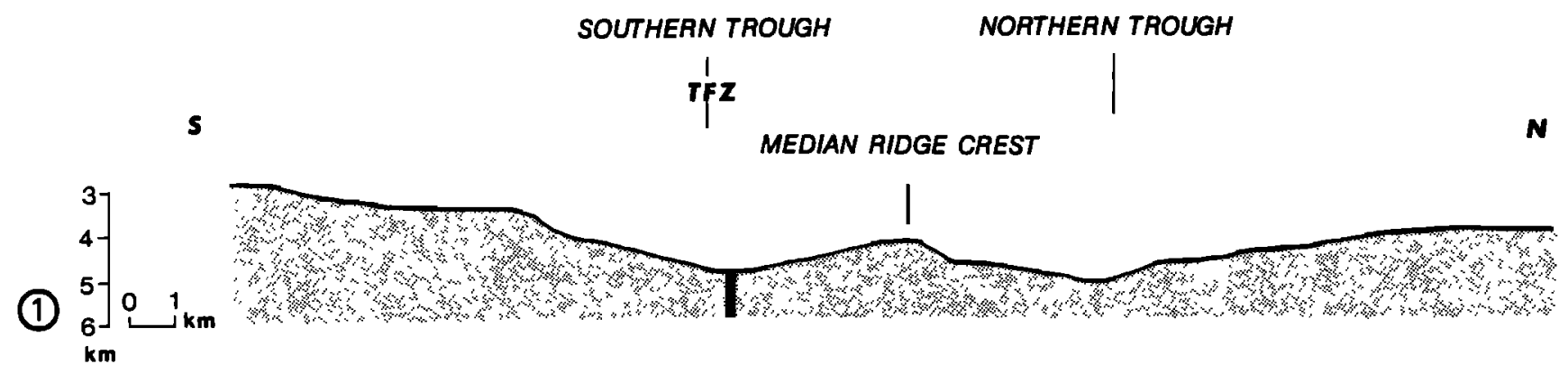

no v.e.

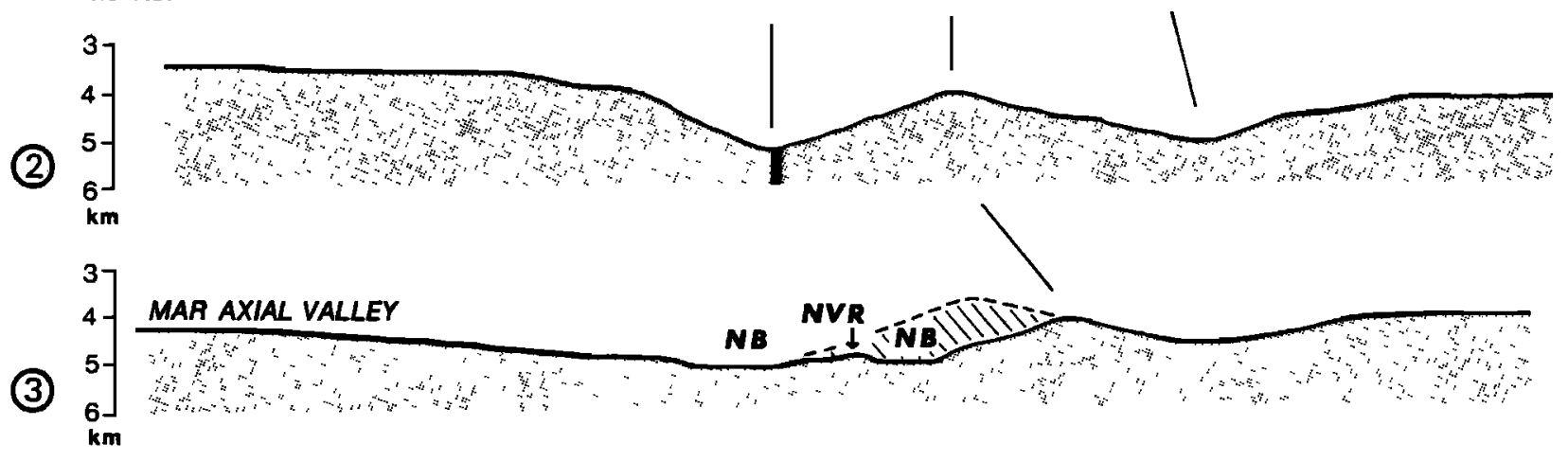

NB : Nodal Basin

NVR : Neovolcànic Ridgè

TFZ : Transform Fault Zone

Fig. 3. Three N-S sections of the Vema median ridge (see Figure 2 for location). Hatched area in section 3 represents the median ridge topography according to section 2 . This suggests that the southem flank of the median ridge has undergone local subsidence in response to the creation of the nodal basin. There is no vertical exaggeration.

characterized by low velocities and thus by a low bulk density. Detrick et al. [1982] proposed that these anomalously low velocities and densities resulted from intense fracturing and hydrothermal alteration of the transform valley crust and upper mantle. An important consequence of such low crustal densities is that the transform valley is not in local isostatic equilibrium: the western part of the Vema transform valley may be about $1 \mathrm{~km}$ deeper than its equilibrium depth [Detrick et al., 1982]. Seismic and gravity profiles across the transform valley [Potts et al., 1986; Louden et al., 1986; Robb and Kane, 1975; Prince and Forsyth, 1988] suggest that the crust is locally significantly thinner beneath the transform valley walls. Along the southern wall, this thin geophysically defined crust appears to coincide with outcrops of serpentinized mantlederived peridotites [Auzende et al., 1989; Cannat et al., 1991].

\section{MORPHOSTRUCTURAL UNITS OF THE EASTERN VEMA RTI}

Before the Nautile diving cruise in 1988, the eastern Vema RTI had been the subject of a Seabeam survey (D. Needham, unpublished map, 1978) and a high resolution deep tow study [Macdonald et al., 1986]. As shown in Figure 4 where dive tracks are reported, our geological survey with the submersible Nautile explored all the distinct morphostructural provinces of the RTI: the Mid-Atlantic Ridge valley axis which deepens progressively toward the north, the nodal basin at the RTI which comprises a westem and an eastern basin separated by the neovolcanic ridge, the southern and northern walls of the transform valley, and the southern and northern troughs of the transform valley, separated by the median ridge.
Macdonald et al. [1986] have shown that the axial neovolcanic zone and the normal faults located on the western edge of the RTI are trending $20^{\circ}-40^{\circ}$ oblique to the north-south spreading axis orientation, as a result of the transmission of shear stresses from the transform system to the rift system. They also indicate that the shear zone is $2-4 \mathrm{~km}$ wide near the eastern RTI and narrows to a 20-100 m wide single tectonized furrow $20 \mathrm{~km}$ west of the RTI. They interpret the median ridge as a serpentinized ultramafic intrusion rising up as a screen through the highly fractured crust of the transform fault zone.

Results concerning the recent and present-day tectonic and volcanic activities of the nodal basins and the southem trough have been published in two previous papers [Auzende et al., 1990; Mamaloukas-Frangoulis et al., 1991]. The most important results of our Nautile dive observations can be summarized as follows:

1. The present-day displacement zone (PDDZ, as defined by Mamaloukas-Frangoulis et al. [1991]; Figure 4) along which plate motion is focused can be traced within the southern trough of the transform valley. It corresponds to an extremely narrow belt, less than $300 \mathrm{~m}$ wide, showing evidence of active deformation, mainly closely spaced parallel fault scarps and open fissures within talus and soft sediments.

2. Closer to the intersection area, the present-day displacement zone runs E-W and thus crosscuts the neovolcanic ridge. Consequently, the northern part of the nodal basin is connected to the median ridge.

3. Both eastem and western nodal subbasins are entirely floored with fresh basalts, contrasting with some other RTIs such as the Kane and Oceanographer RTIs where deep crustal or 


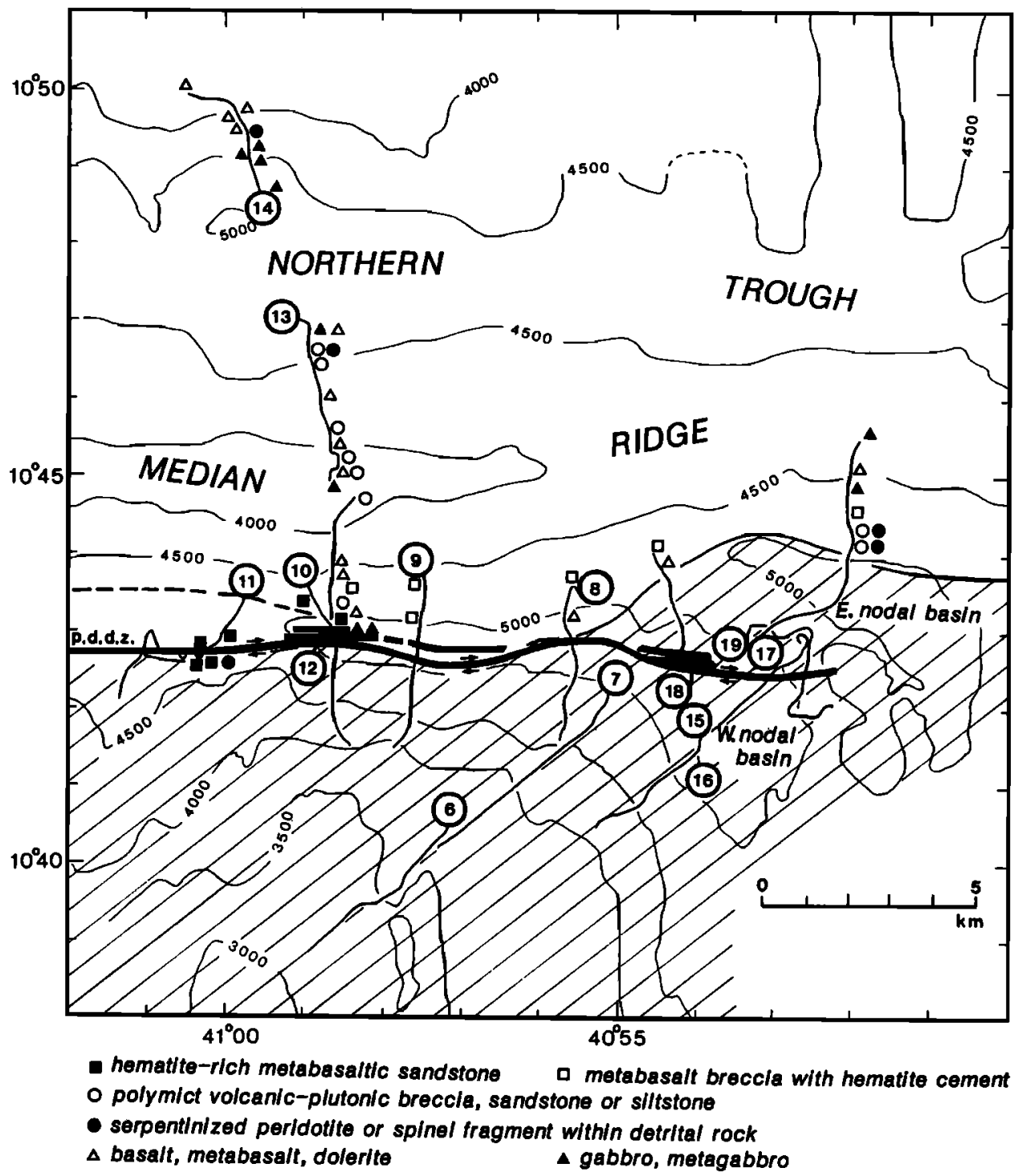

7 area where fresh to relatively tresh basalts have been recovered

Fig. 4. Bathymetric map of the Vema eastem RTI and location of the samples collected from the median ridge and from the northem wall of the eastern Vema transform fault intersection domain during the Nautile dives (encircled numbers). The line marked "p.d.d.z." represents the present-day displacement zone according to Mamaloukas-Frangoulis et al., [1991].

upper mantle rocks are exposed. This indicates that the intersection area has recently been the site of abundant magmatic activity.

The main morphological feature of the Vema eastem RTI is that the transform valley is divided into a northem and a southern trough by the median ridge (Figures 2 and 3 ). This E$\mathrm{W}$ trending feature is continuous from $41^{\circ} 21^{\prime} \mathrm{W}$ to the eastemmost part of the mapped area, at $40^{\circ} 40^{\prime} \mathrm{W}$. It reaches its maximum elevation $(3400 \mathrm{~m})$ at $41^{\circ} 00 \mathrm{~W}$. Immediately to the north of the MAR axis, the crest of the median ridge is shallower and exhibits an arcuate shape. This bend in the ridge crest contrasts with the linear trace of the axis of the northern trough. The width of the median ridge $(7 \mathrm{~km})$ is relatively constant to the west and to the east of the intersection area, while it decreases to less than $5 \mathrm{~km}$ at the northern tip of the MAR axis.

\section{The Vema MEdian RIDGe AND ADJACENT AREAS: DIVE OBSERVATIONS AND SAMPLE STUDIES}

Previous to our dives in the RTI region, data regarding the lithology of the Vema median ridge were obtained at two sites. One site (R/V Charcot, 1977 , about $41^{\circ} 00 \mathrm{~W}, 10^{\circ} 45 \mathrm{~N}$, dredge 9) released undeformed basalt fragments, cataclastic brecciated basalts and sedimentary basaltic breccias [Mével, 1981]. However, this location was wrongly believed to be along the southern wall of the fracture valley. Improved navigation of the bathymetry map has now revealed that this previous dredge haul was located along the southern flank of the median ridge. Most of the basaltic fragments show extensive greenschist alteration with numerous chlorite veins, pumpellyite, growth of white micas within albitized plagioclases, etc. Another site is on the northem flank of the "Vema mound" between $41^{\circ} 50^{\prime} \mathrm{W}$ and $41^{\circ} 55^{\prime} \mathrm{W}$ (Figure 1), where the R/N Conrad (cruise RC 21) 


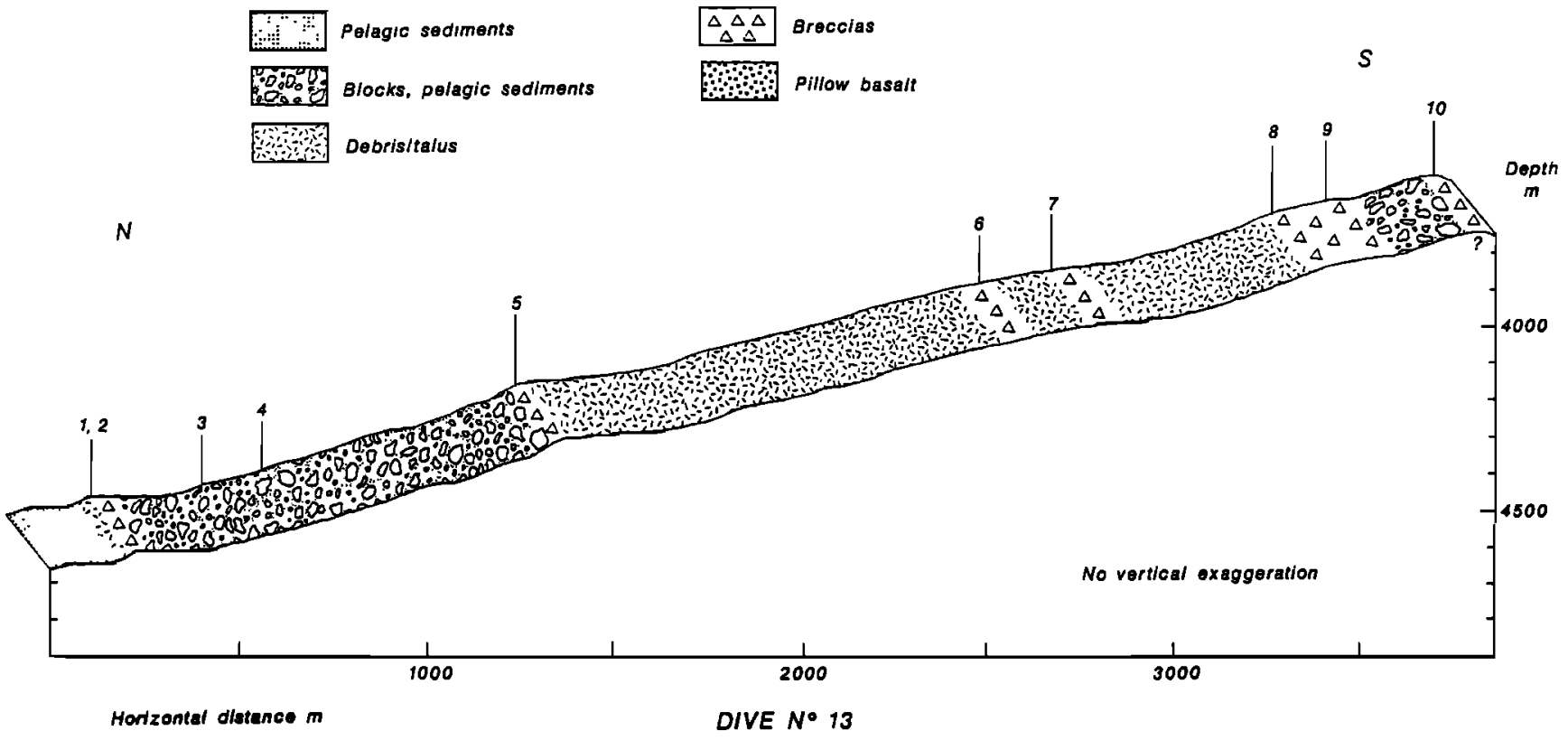

Fig. 5. Geologic reconstruction of Nautile dive 13 (northern flank of the median ridge; without vertical exaggeration). Numbers (1 to 10) indicate locations of samples collected along the dive. See Figure 4 for location of dive track.

dredged peridotites (25\% by weight); gabbros and metagabbros it is not possible to assess whether the massive rocks observed $(55 \%)$; volcaniclastic material $(15 \%)$ and basalt $(5 \%)$ (E. here represent exposures of the ridge basement or wide blocks Bonatti, unpublished data, 1984).

Nautile dives 13 and 12 were entirely devoted to the study of the northern and southern flanks, respectively, of the median ridge (Figure 4, 5, and 6). The results allow the reconstruction of a speculative NS transect of the ridge (Figure 7). Additional information concerning the lithology of the ridge and its geological boundaries with the southern valley and the nodal basin has been obtained from dives 8, 9, 10, 11, 17 and 18 (Figure 4).

\subsection{The Northern Flank of the Median Ridge (Dive 13)}

Dive 13 begins at $4658 \mathrm{~m}$, that is, $500 \mathrm{~m}$ higher than the deepest part of the northem trough, in a flat area floored with recent pelagic ooze (Figure 5). The dive ends at the summit of the median ridge $(3750 \mathrm{~m})$, less than $1 \mathrm{~km}$ to the northwest of the endpoint of dive 12. The slope of the ridge is regular and moderate and is covered with abundant, white pelagic sediments. Ripple marks resulting from very active bottom currents have been observed at the foot of the ridge. The smooth surface of sediments is cut from place to place by moderately steep scarps, $1 \mathrm{~m}$ to a few meters high, locally more (up to $30 \mathrm{~m}$ at $3810 \mathrm{~m}$ ), that expose only poorly consolidated, subhorizontal polymictic breccias showing rounded to angular, decimeter-sized clasts of metagabbros and metabasalts in a fine-grained matrix. Large blocks, a few decimeters wide, are found either isolated on the pelagic sediments or partially buried within the breccias. A thin ferromanganese crust can be observed on the outcrops as well as on the samples collected, indicating that rock exposure did not occur very recently. Locally, along the highest scarps, graded bedding within the breccias can be observed suggesting rapid emplacement by gravity flows. The crest of the median ridge shows relatively continuous exposures of angular rocks and isolated blocks with characteristics typical of dolerites and gabbros. No pillow fragments or lava tubes were observed here and the only sample recovered is a gabbro (sample VE 13-10, Figure 9c). However, within a very coarse detrital formation.

Observations made during dive 13 show that the northern flank of the Vema median ridge lacks evidence of recent tectonic activity. This contrasts strongly with the southern flank of the ridge where evidence of recent faulting is abundant (see below). Nevertheless, the scarps exposing the breccias are probably the trace of now inactive major normal faults.

Samples collected during the dive are either clasts recovered in situ from the breccias and from talus at the base of the scarps, or pieces of poorly consolidated breccias. The lithology of the largest clasts is variable. Metagabbros, metabasalts and metadolerites, showing a strong greenschist metamorphism overprint, are the most abundant rocktypes. Small fragments of serpentinized peridotites and detrital spinels were found locally in one microbreccia sample (VE 133; Table 1). The protolith of these serpentinized peridotite fragments appears to have been a clinopyroxene-rich harzburgite, or a lherzolite, with a porphyroclastic texture typical of upper mantle rocks. The fine-grained matrix of the breccias is composed of small lithic fragments and of detrital minerals such as pyroxenes, more or less albitized plagioclases, green to pale green amphiboles, epidote, chlorite and hematite. Fragments of microfossils and micrite grains are also found within the matrix of the breccias.

\subsection{The Southern Flank of the Median Ridge to the West of the Nodal Basin: \\ Observations During Dives}

\section{$8,9,10,11$ and 12}

Dive 12. Three successive formations have been observed during dive 12 along the section across the southern flank of the median ridge (Figure 6).

1. The base of the ridge flank consists of semiconsolidated to consolidated basaltic and gabbroic sedimentary breccias. These detrital formations have been observed and sampled along the basal slopes of the ridge but also along a very recent 


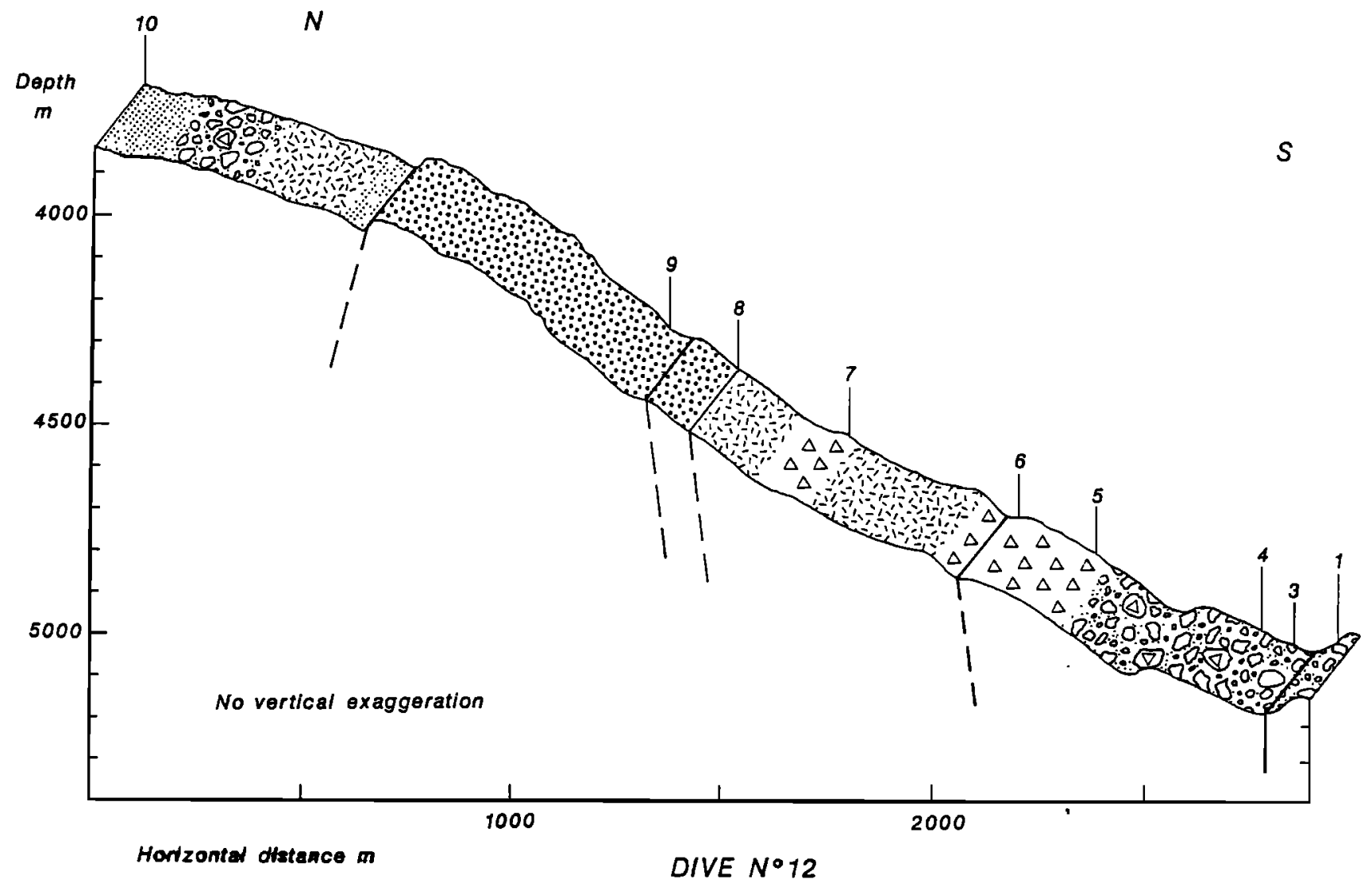

Fig. 6. Geologic reconstruction of Nautile dive 12 (southem flank of the median ridge; without vertical exaggeration). Numbers $(1$ to 10$)$ indicate locations of samples collected along the dive. See Figure 4 for location of dive track and Figure 5 for key to symbols used. Blocks with triangle represent breccia blocks. Heavy lines represent active or inactive faults; the dip of faults is hypothetical.

fault scarp located in the valley floor at $5149 \mathrm{~m}$ and representing an active splay of the present-day displacement zone [Mamaloukas-Frangoulis et al., 1991]. The breccias are exposed from 5100 to $4500 \mathrm{~m}$ along scarps separated by gentle, south dipping slopes covered with white pelagic sediments (Figure 6). All exposures are free of ferromanganese crust and fresh debris slides are abundant suggesting recent exposure and active tectonism. It is rare that the criteria allowing good resolution of the general attitude of the bedding of the breccias are met. At one place, however $(4863 \mathrm{~m})$, a horizontal contact between white and red breccia layers, some decimeters thick, has been observed. In other places, horizontal bedding is defined by the attitude of red microbreccia layers interbedded within coarser breccias.

Submersible observations as well as thin section studies of samples (Figure 10 and Table 1) indicate that the material reworked within the breccias observed during the first part of dive 12 is highly heterogeneous. Fragments of metagabbros, metadolerites, metabasalts and isolated detrital minerals such as weathered plagioclase, more or less amphibolitized pyroxene, green amphibole, chlorite, and epidote are the usual components of the breccias. The nature of the clasts demonstrates that the source of this material corresponds to different levels of oceanic crust that underwent extensive greenschist metamorphism. Less abundant fragments of upper mantle material such as serpentine and spinel are also found in the breccias (Figure 10 and Table 1). The size of the mafic fragments usually ranges from $1 \mathrm{~mm}$ to some centimeters, but blocks of massive rocks, more than $1 \mathrm{~m}$ wide, were commonly observed during the dive. Thin section observation reveals that some microbreccias are affected by pervasive cleavages, shear bands and recumbent folds (Figure 10b). These microstructures are linked to displacements along faults which crosscut the breccias. Numerous gabbroic fragments show cataclastic deformation. However, it is unclear whether these rocks were deformed prior to or after their deposition within the breccias.

A few samples show a dark red color related to high hematite content. Hematite is present both within the metabasaltic clasts and within the fine-grained sedimentary matrix of the breccias. As discussed below (section 5), the abundance of hematite is probably due to extended low temperature hydrothermal circulation within major fractures that crosscut the ridge. It must be pointed out that such hematite-bearing breccias have not been found on the northern flank of the median ridge and thus appear to be restricted to this part of the section. Hematite-rich metabasaltic breccias were also recovered farther west, along the southern flank of the ridge and along the present-day displacement zone during dives $8,9,11$, 12, 17 and 18 (Figure 12).

At $5156 \mathrm{~m}$, a small escarpment, a few meters high, exposes massive rocks, showing regularly spaced vertical cleavages, representing probably sheeted dykes. This exposure may represent the crustal basement of the median ridge rather than a voluminous block enclosed within the detrital formation.

2. The second formation consists of pillow basalts, massive lavas and basaltic breccias exposed from 4400 to $4000 \mathrm{~m}$ depth 


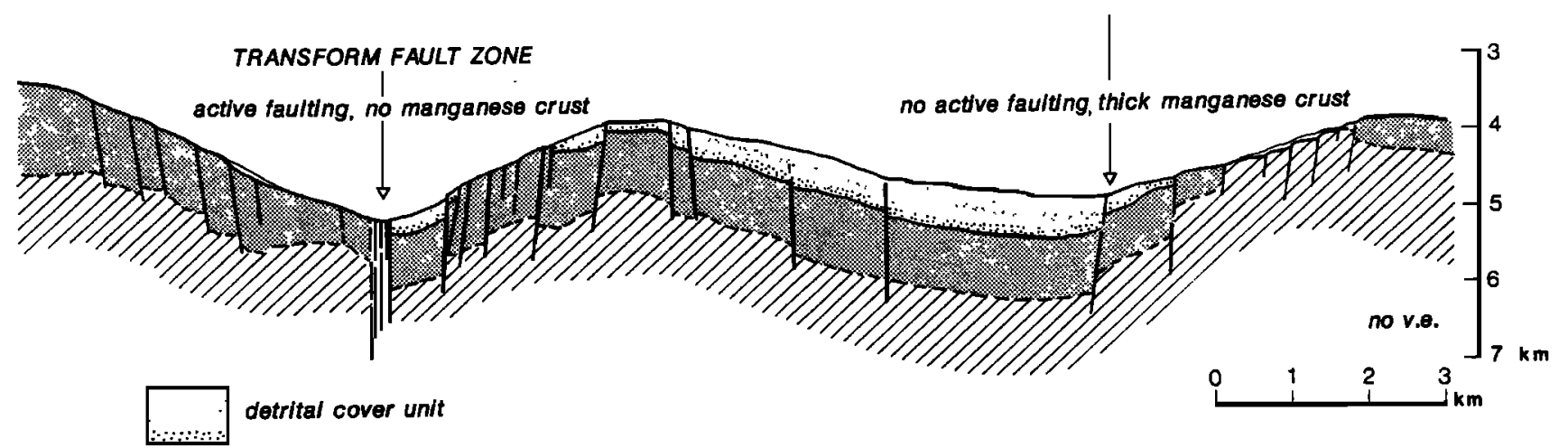

upper crust (basalts, dikes,

lower crust and mantle

Fig. 7. Synthetic N-S geological section of the transform walls and the median ridge of the Vema $\mathrm{FZ}$ at $40^{\circ} 59{ }^{\prime} \mathrm{W}$, based mainly on geological observations during dives $10,12,13,14$. Section is shown without vertical exaggeration.

along numerous vertical escarpments separated by steps covered with unconsolidated pelagic sediments (Figure 6). Very recent faulting in this part of the section is evidenced by the abundance of fresh fault scarps principally striking E-W, N140 and $\mathrm{N} 50$ and by the local occurrence of exposed fault planes. At $4089 \mathrm{~m}$, a vertical, N140 trending, fault plane shows clear striae with a moderate southward pitch $\left(0^{\circ}\right.$ to $\left.20^{\circ}\right)$, indicating both vertical and lateral displacement along the fault.

Due to the fact that the second formation is exposed almost continuously from $4400 \mathrm{~m}$ to $4000 \mathrm{~m}$ without any interval of polymictic breccia or any outcrop of gabbro and peridotite, we tentatively suggest that the basalts represent exposure of the crustal basement of the median ridge. Such an interpretation should be confirmed by further lateral submersible explorations or drilling.

3. Dive 12 ends in the third formation which consists of gabbroic and basaltic sedimentary breccias (sample VE 12-10, Figure $10 d$ ). The breccias sparsely crop out along gentle, muddy slopes from $4000 \mathrm{~m}$ to the top of the ridge at $3800 \mathrm{~m}$. In contrast to the regions explored earlier during the dive, the last part of the transect is characterized by gentle relief and by the lack of steep scarps and recent talus (Figure 6). This indicates that this area is tectonically inactive. This third formation is probably the southward extension of the detrital formation exposed along the northern flank of the median ridge and sampled during dive 13.

Dives $8,9,10$ and 11 . Poorly consolidated to consolidated polymictic mafic breccias and microbreccias with hematitic matrix as well as mafic graded-bedded sandstones containing abundant greenschist detrital minerals (albite, chlorite, actinolite, amphibolitized pyroxenes) were observed and sampled at the foot of the southern flank of the median ridge during dives 8, 9, 10 and 11 (Table 1 and Figure 10e). The active faults which characterize the present-day displacement zone crosscut these detrital formations only in the westernmost part of the surveyed area, i.e., west of $40^{\circ} 58^{\prime} \mathrm{W}$ (dives 10,11 and 12 , Figures $9 c$ and $9 d$ ). Very fresh scarps, V-shaped valleys with active debris slides were commonly observed both on the valley floor and on the foot of the median ridge [Auzende et al., 1989; Mamaloukas-Frangoulis et al., 1991]. The rocks exposed along these scarps are mainly sedimentary breccias showing locally clear horizontal bedding outlined by variably colored layers (Figure 9e). In some places, the breccias are deformed in fault gauges and exhibit tectonic cleavages and slickensides. Thin sections of samples collected in situ or from talus at the base of the scarps show a well developed schistosity. In two places only basaltic tubes and pillows are exposed along scarps located in the valley floor (dive 11) or at the foot of the median ridge (dive 10). This indicates that the detrital cover is locally thin or absent due either to initial reduced thickness or to further faulting. It is unclear however whether the detrital formations observed on the valley floor represent debris flows emplaced recently in relation to tectonic events which affected the southem flank of the median ridge, or older detrital deposits corresponding to the initial cover of the median ridge.

In contrast to results of dives 10 and 11 , observations made during dives 9 and 8 , to the east of $40^{\circ} 58^{\prime} \mathrm{W}$, indicate that active faults of the present-day displacement zone cut through fresh pillows belonging to the base of the southern wall of the transform. Therefore, the boundary between the median ridge and the volcanic formations of the southern wall of the transform tends to trend NE-SW between $40^{\circ} 58^{\prime}$ and $40^{\circ} 55^{\prime}$. Thus, the active faults of the present-day displacement zone do not always correspond to the southern geological boundary of the median ridge.

\subsection{The Median Ridge to the North of the RTI and Its Boundary With the Nodal Basin (dives 17 and 18)}

The major part of dive 18 observations concern the western nodal basin of the RTI, and the recent volcanic constructions located along the neovolcanic ridge. From $5200 \mathrm{~m}$ to $5100 \mathrm{~m}$, in a relatively flat volcanic area located on the northern edge of the western nodal basin, we crossed a set of parallel, closely spaced fault traces marked by $V$-shaped furrows, funnel alignments in the sediments and fresh scarps cutting through 
TABLE 1. Brief Description of Samples Collected During Nautile Dives Along the Vema Median Ridge

\begin{tabular}{ccc}
\hline $\begin{array}{c}\text { Sample } \\
\text { Numbers }\end{array}$ & $\begin{array}{c}\text { Depth, } \\
\text { mbsl }\end{array}$ & Brief description \\
\hline
\end{tabular}

Dive 8

VE08-1

VE08-2

Dive 9

VE09-1

VE09-2

Dive 10

VE10-1

4695

5066

4810

Dive 11

VE11-1

VE11-2

VE11-3
Sedimentary basaltic breccia with red matrix (Fe-oxides). Clasts from rims and core of weathered pillows. Radiolaria and Foraminifera are present in the matrix.

Cataclastic chloritized basalt.

Sedimentary basaltic breccia with red matrix (Fe-oxides).

Sedimentary basaltic breccia with red matrix (Fe-oxides).

Red (hematite rich), mafic greenschist, graded-bedded sandstone. Contains $1 \mathrm{~mm}$-sized lithic clasts (basalts, dolerites and weathered basaltic glass) and smaller fragments of isolated minerals (plagioclases, pyroxenes, amphibolitized pyroxenes, chlorites, amphiboles, hematite) and micrite grains.

Deformed, mafic greenschist microbreccia with red matrix (hematite and Fe-oxides). Contains millimetersized clasts of metadolerite, and isolated fragments of minerals (plagioclases, pyroxenes, amphibolitized pyroxenes, green amphiboles, actinolite, chlorite, hematite) and micrite grains.

Sedimentary basalt breccia (clasts up to a few centimeters in diameter) in a matrix of red basaltic sandstone showing graded bedding and local schistosity. Chlorite-calcite veins crosscut the breccia.

Polymictic greenschist facies breccia. Clasts are dominantly basalts showing various textural types. Fragments of sedimentary basaltic breccias are common. The rock also contains rare detrital spinel as well as fragments of pyroxene-rich sandstones.

Greenschist facies dolerite with cataclastic deformation.

Brownish pelagic sediment.

Gabbro.

Talc-chlorite mylonite with hydrogamet, probably a strongly deformed roddingite.

Deformed mafic layered sandstone. The rock is composed of alternating red and green layers, $1 \mathrm{~mm}$ thick, showing isoclinal folds. Red layers contain hematite grains and small fragments of chlorite, epidote and actinolite. Green layers contain detrital pyroxenes and needles of green amphibole in a chloriterich matrix. No fresh plagioclases have been observed.

Aphyric basalt.

Greenschist facies gabbro breccia. The breccia contains large rounded clasts of greenschist metagabbro in a matrix of gabbroic sandstone with abundant fragments of clinopyroxenes, altered plagioclases, green amphiboles and chlorite. Micrite grains are present. Serpentinite fragments have been observed.

Pillow breccia with hematite-rich matrix.

Chloritized metadolerite

Cataclastic metabasalt with quartz-chlorite veins.

Greenschist mafic polymictic breccia with metagabbro, metadolerite and metabasalt fragments. Isolated detrital minerals such as pyroxenes, amphiboles and plagioclases are abundant within the matrix. The rock contains rare detrital spinel. Clasts are matrix-supported. A prehnite-quartz vein crosscuts the breccia.

Gabbro.

Dolerite.

Dolerite.

Metagabbro block from an unconsolidated polymictic breccia.

Poorly consolidated polymictic breccia with a matrix of mafic sandstone and siltstone containing isolated plagioclases, pyroxenes, large amphiboles, epidote, chlorite, hematite and spinel. Micrite grains and microfossils fragments are also present.

A centimeter-sized clast from breccia VE13-3-1: serpentinized, undeformed lherzolite with fresh orthopyroxene and clinopyroxene.

Fragments of basalt and gabbro from an unconsolidated polymictic breccia.

Dolerite.

Poorly consolidated greenschist polymictic breccia with angular to rounded clasts of metabasalt and metagabbro in a fine-grained matrix of mafic greenschist sandstone.

Metabasalt.

Poorly consolidated greenschist plutonic microbreccia. Lithic and crystal fragments derive principally from gabbroic rocks. Chlorite and amphibolitized pyroxenes are abundant within the matrix of the microbreccia.

Metadolerite block set in a mafic greenschist sandstone.

Gabbro.

Greenschist polymictic coarse to fine-grained sandstone. Both samples show graded beddings and crossbeddings. They contain lithic fragments of basalt, dolerite and microgabbro and minor serpentinite, and related detrital minerals (clinopyroxene, chlorite, hematite, spinel, serpentine). 
TABLE 1. (continued)

\begin{tabular}{|c|c|c|}
\hline $\begin{array}{l}\text { Sample } \\
\text { Numbers }\end{array}$ & $\begin{array}{l}\text { Depth, } \\
\text { mbsl }\end{array}$ & Brief description \\
\hline $\begin{array}{l}\text { VE17-3 } \\
\text { VE17-4 }\end{array}$ & $\begin{array}{l}4790 \\
4654\end{array}$ & $\begin{array}{l}\text { Greenschist bedded siltstone. Same elements as samples VE17-2. } \\
\text { Sedimentary mafic breccia. It consists of angular fragments of dolerite and isolated minerals showing a } \\
\text { greenschist facies overprint set in a red, fine-grained matrix (Fe-oxides). }\end{array}$ \\
\hline $\begin{array}{l}\text { VE17-5 } \\
\text { VE17-7 } \\
\text { VE17-8 }\end{array}$ & $\begin{array}{l}4529 \\
4481 \\
4219\end{array}$ & $\begin{array}{l}\text { Gabbro. } \\
\text { Fine-grained dolerite. } \\
\text { Gabbro. }\end{array}$ \\
\hline $\begin{array}{l}\text { Dive } 18 \\
\text { VE18-6 } \\
\text { VE18-7 }\end{array}$ & $\begin{array}{l}4769 \\
4725\end{array}$ & $\begin{array}{l}\text { Cataclastic metadolerite breccia. } \\
\text { Sedimentary basalt breccia with red matrix (Fe-oxides). }\end{array}$ \\
\hline
\end{tabular}

Here, mbsl denotes meters below sea level.

pillows. These features are inferred to be the surficial expression of the present-day displacement zone [MamaloukasFrangoulis et al., 1991]. At the end of the dive, i.e., from 4800 $\mathrm{m}$ to $4700 \mathrm{~m}$, we reached the southern flank of the median ridge. This area is characterized by tectonically inactive, highly sedimented smooth slopes, contrasting with the rough topography of the neovolcanic zone previously observed during this dive. Locally, a chaotic mixture of meter sized, angular blocks is partially buried in the sediments. Samples collected include a cataclastic metadolerite breccia (VE 18-6) and a fragment of mafic sedimentary breccia with hematite-rich matrix (VE 18-7). Both samples show a well-developed ferromanganese crust, more than $1 \mathrm{~cm}$ thick on sample VE 187, indicating old exposure. The clasts of breccia VE 18.7 consist of centimeter sized, angular fragments of greenschist facies metabasalts set in a fine-grained matrix containing lithic fragments and isolated minerals such as plagioclases, hematite, chlorite and actinolite.

No mark of any recent tectonic activity was observed at the boundary between the neovolcanic ridge and the median ridge. Consequently, the median ridge appears now to be welded to the

$N$

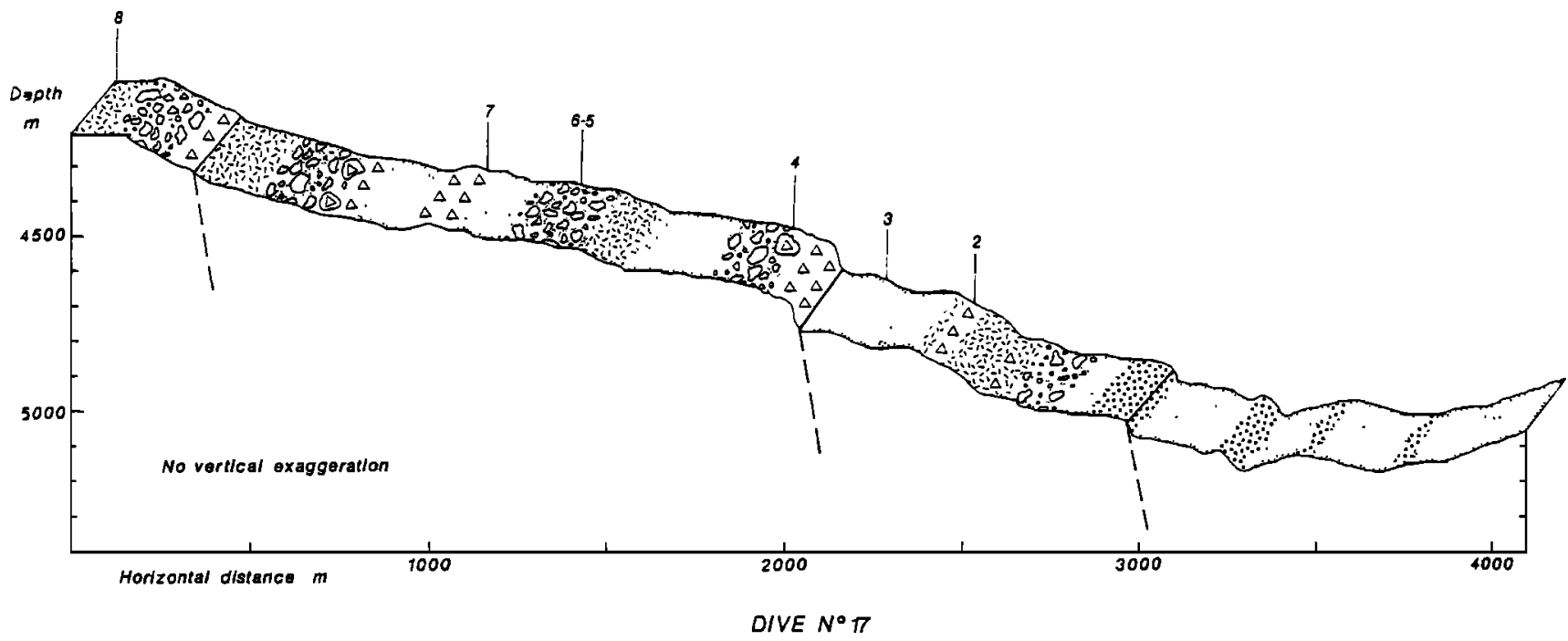

Fig. 8. Geologic reconstruction of Nautile dive 17 (southern flank of the median ridge at the tip of the MAR axis; without vertical exaggeration). Numbers ( 1 to 8 ) indicate locations of samples collected along the dive. See Figure 4 for location of dive track and Figure 5 for key to symbols used. Heavy lines represent active or inactive faults; the dip of faults is hypothetical. neovolcanic zone. Furthermore, this confirms the results of dive 8 showing that the present-day displacement zone is not the geological boundary between the median ridge and the

Dive 17 provides a complete section of the southern flank of the median ridge to the east of the neovolcanic ridge and to the north of the eastern nodal basin (Figure 4). The dive begins on the western flank of the neovolcanic ridge $(4958 \mathrm{~m})$ in an area showing fresh volcanic formations, mainly basaltic pillows and lava tubes, and fresh talus, and continues to the floor of the eastern nodal basin (5172 m; Figure 8). The sedimentary infill appears to be thick and no mark of recent tectonic activity was observed on the western wall and the flat floor of the basin. Both observations suggest that the faults responsible for the subsidence of the nodal basin are now inactive. Farther upslope, at $5071 \mathrm{~m}$, on the northern wall of the eastem nodal basin we observed a vertical fault scarp exposing sections of pillows slightly dusted with pelagic sediments (Figure 8). No debris was observed at the foot of the scarp, because of a thick sedimentary cover, suggesting that the fault is inactive. This scarp probably represents one of the major normal and/or recent volcanics emplaced in the RTI domain. 

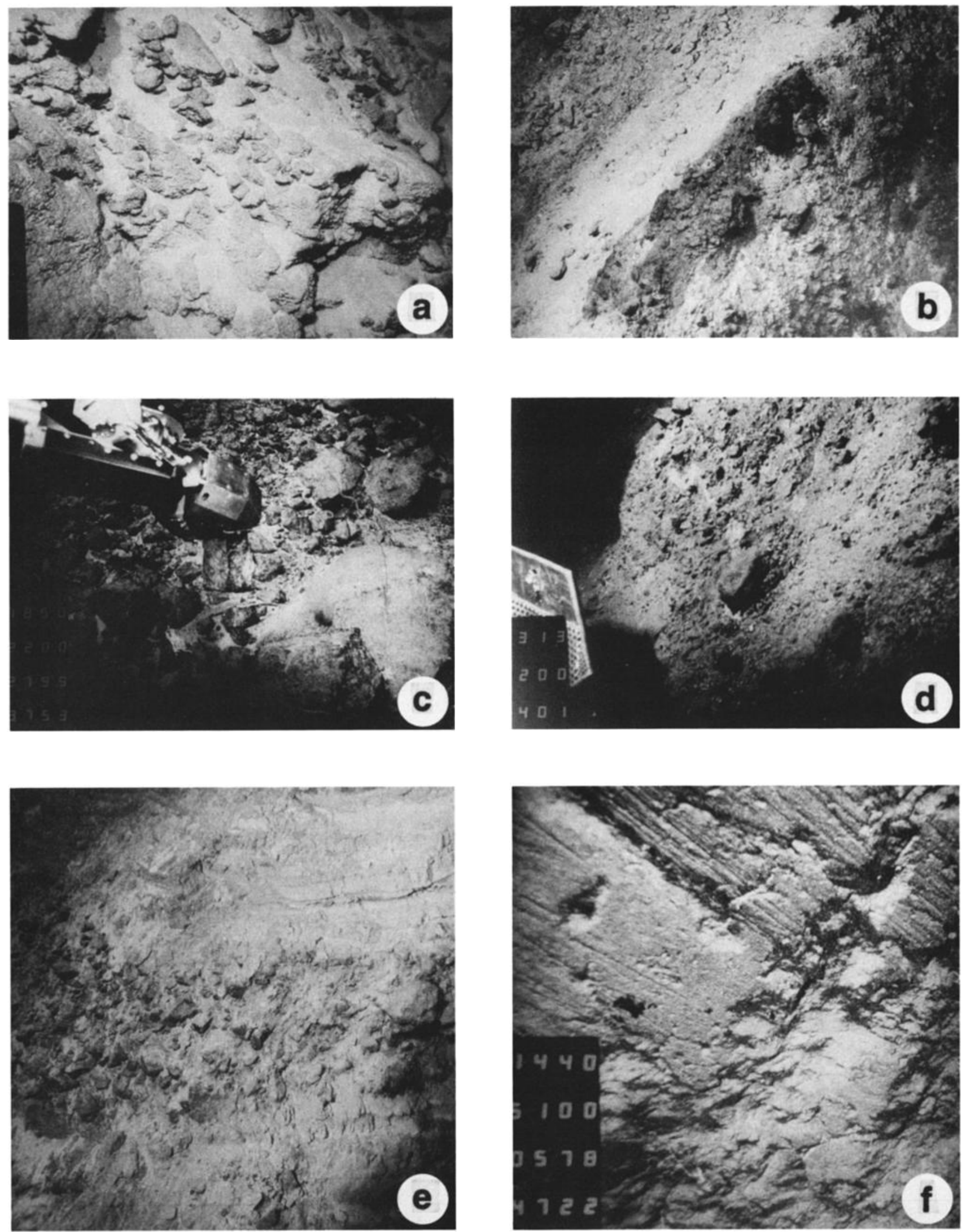

Fig. 9. (caption on following page) 
strike-slip faults that accommodated the formation of the nodal basin.

Farther north, the dive track crosses a narrow E-W trending, sediment-covered valley and enters the median ridge domain where no fresh volcanics were observed (Figure 8). Rock types similar to the detrital formations capping the median ridge farther west were observed and sampled at $5000 \mathrm{~m}$, immediately after the narrow valley. These are isolated blocks of massive, tabular graded-bedded sandstones and siltstones a few meters wide. Thin section analyses of samples VE 17-2 collected in this area reveal that the coarser sandstones are made up of variously altered millimeter sized fragments of dolerite and basalt, palagonitized basaltic glass, and isolated mineral grains such as large clinopyroxene derived most likely from plutonic rocks, amphibolitized pyroxene and minor spinel and orthopyroxene. Minor lithic components are fragments of serpentinite and microgabbro. Hematite is common in most of the lithic fragments. Associated siltstones (sample VE 17-3) are composed of isolated mineral debris including plagioclase, amphibole, chlorite, pyroxene, hematite, spinel, and palagonitized glass shards.

The nature of the reworked material in the breccias and sandstones is similar to that of clasts found in breccias recovered all along the southern wall of the median ridge. The occurrence of fine-grained sediments such as greenschist facies sandstones and siltstones suggests that the detrital material suffered significant transport before deposition.

The sandstones are better exposed higher up, at $4755 \mathrm{~m}$, along a N110-N90 trending, $80 \mathrm{~m}$ high, vertical scarp (Figure 8) corresponding to an inactive major fault. Relict fault planes with striae dipping $45^{\circ}$ to $30^{\circ}$ to the west are still visible locally on this scarp (Figure 9f). We interpret this fault surface as a now inactive dextral strike-slip fault with a vertical component, allowing the southern flank of the median ridge to subside toward the nodal basin. The average present-day dip of the sandstones is $30^{\circ}$ to the west. These structural observations confirm that the median ridge was subjected to local tilting in response to normal and strike-slip faulting.

After this scarp, the slope becomes more gentle. We observed frequent chaotic blocks of mafic breccias composed of angular, matrix-supported clasts of greenschist metabasalts, dolerites and microgabbro and isolated minerals (sample VE 17-4; Table 1 and Figure 10a). The matrix of the breccias shows the high hematite content that characterizes the samples collected along the southem boundary of the median ridge. The dive ended at $4216 \mathrm{~m}$ in an area of complex morphology with chaos of blocks and talus of various lithology, mainly mafic breccias and gabbros. The abundance of gabbroic rocks might suggest that this rock type forms the basement of the ridge.
However, no definitive observation confirms this hypothesis. Here again, the gabbro blocks could be large fragments included in a very coarse detrital formation emplaced on the basement of the median ridge.

\section{SUMMARY OF MAIN RESULTS}

\subsection{The Detrital Cover of the Median Ridge}

Submersible observations show that the Vema median ridge is capped by a detrital cover (Figures 7 and 11) which consists of a succession of polymictic sedimentary breccias, sandstones and siltstones made up of metabasaltic, doleritic, and gabbroic clasts, with less frequent serpentinite and spinel fragments. Most of the rocks have been subjected to greenschist facies metamorphism prior to-their incorporation within the detrital cover. The composition of the clasts suggests that the detrital cover originated from the disaggregation of outcrops of various crustal and upper mantle oceanic rocks. The occurrence of sandstone and siltstone horizons indicates that the detrital material was significantly transported prior to deposition; and the graded bedding occasionally observed within detrital beds suggests emplacement by gravity flows. The northern flank of the ridge is entirely covered with such a polygenic detrital formation and shows no evidence of recent tectonics. In contrast, the southern flank of the median ridge to the east of $40^{\circ} 56^{\prime} \mathrm{W}$ was affected by recent faulting and is locally covered by hematite-rich monogenic basaltic breccias and sandstones (Figure 7). Such monogenic formations resulted probably from the in situ brecciation of the median ridge basement.

\subsection{The Basement of the Median Ridge}

It is clear now that the Vema median ridge is not a very recent constructional volcanic feature and can no longer be interpreted as a serpentinized mantle ridge. However, the nature of the basement of the Vema median ridge, beneath the detrital cover, is still a matter for speculation. In our interpretation, the basaltic pillows exposed along the southern flank of the ridge (dive 12) are thought to represent the crustal basement of the ridge. Additional exploration is needed in order to test the lateral continuity of these outcrops although our interpretation is supported by the observation that the pillow formation is exposed almost continuously from $4400 \mathrm{~m}$ to $4000 \mathrm{~m}$ without any interval of polymictic breccia or without any outcrop of gabbro and peridotite. Other smaller outcrops of dykes and gabbros found respectively at the base of the southem flank (dive 12) and at the summit of the ridge (dive 13) remain questionable. Since they are associated with more or less abundant polymictic breccias they cannot be regarded confidently as basement outcrops.

Fig. 9. Nautile bottom photographs of the Vema median ridge and northem transform wall. (a) Typical aspect of the tectonically inactive northem transform wall (dive 14, depth: $4429 \mathrm{~m}$; the field of view is approximately $10 \mathrm{~m}$ wide). Outcrops are capped by a thick manganese crust and partially covered by pelagic sediments. (b) Very fresh scarp at the foot of the southem flank of the median ridge (dive 11 , depth: $4853 \mathrm{~m}$ ) exposing poorly consolidated polymictic sedimentary breccias. Dark patch (approximately $2 \mathrm{~m}$ long) in the center of the photograph corresponds to hematite-rich breccias. (c) Sampling of a gabbro block from the summit of the median ridge (sample 10, dive 13, depth: $3753 \mathrm{~m}$; the field of view is approximately $4 \mathrm{~m}$ wide). The massive rocks observed here represent either exposures of the ridge basement or wide blocks within a very coarse detrital unit belonging to the median ridge cover formation. (d) Poorly consolidated polymictic sedimentary breccias exposed along an active fault scarp at the foot of the southem flank of the median ridge (dive 11, depth: $4922 \mathrm{~m}$; width of field: $5 \mathrm{~m}$ ). (e) Detrital formation showing horizontal bedding outlined by variably colored breccia layers and altemating pelagic sediments (white layers) from the foot of the southern flank of the median ridge (dive 9 , depth: $5038 \mathrm{~m}$; the breccia layer in the middle of the photograph is about $1 \mathrm{~m}$ thick). $(f)$ Detailed view of a $80 \mathrm{~m}$ high fault scarp with oblique striations exposing mafic sandstones at the southern flank of the median ridge (dive 17 , depth: 4722 m; the field of view is about $1 \mathrm{~m}$ wide). 

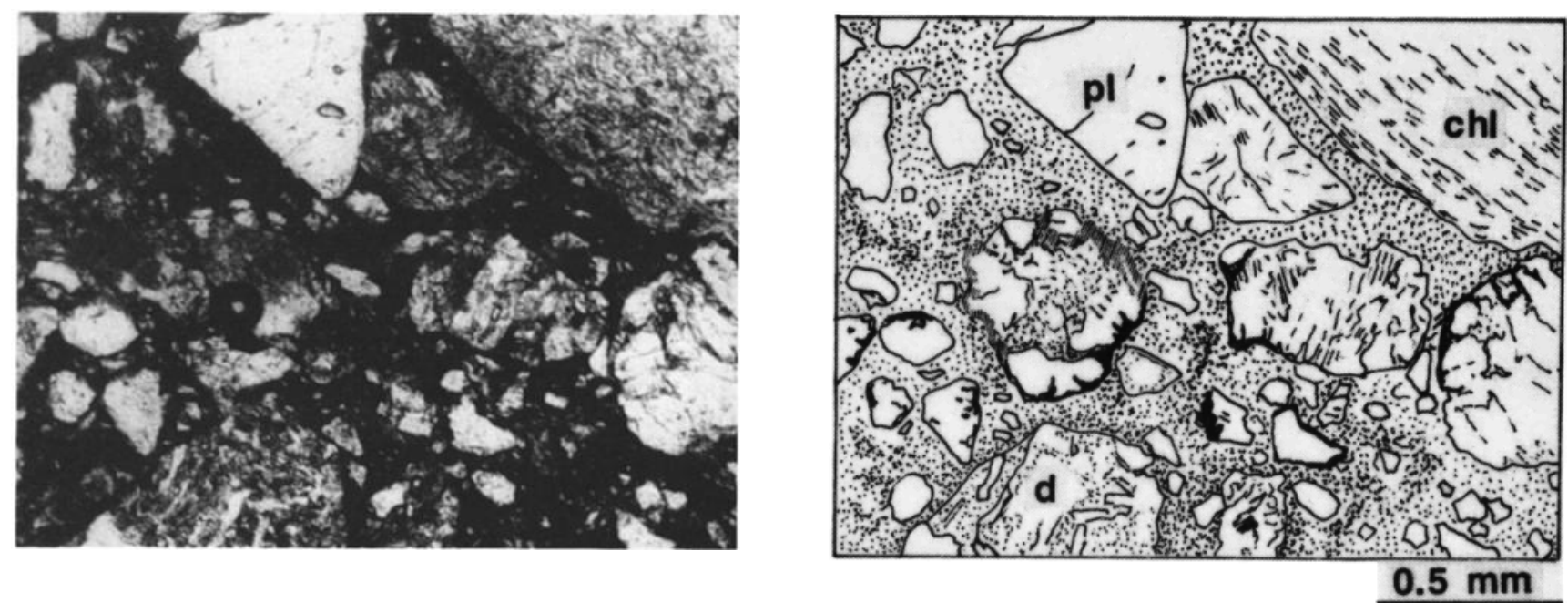

Fig. 10a. Photomicrograph of Sample VE 17-4 (4654 m): sedimentary mafic breccia composed of angular clasts of dolerite (d), chloritized dolerite (chl) and isolated mineral fragments such as amphibolitized pyroxene and plagioclase (pl). The finegrained matrix is a flour of greenschist facies doleritic rocks with abundant iron oxides grains (plane polarized light).
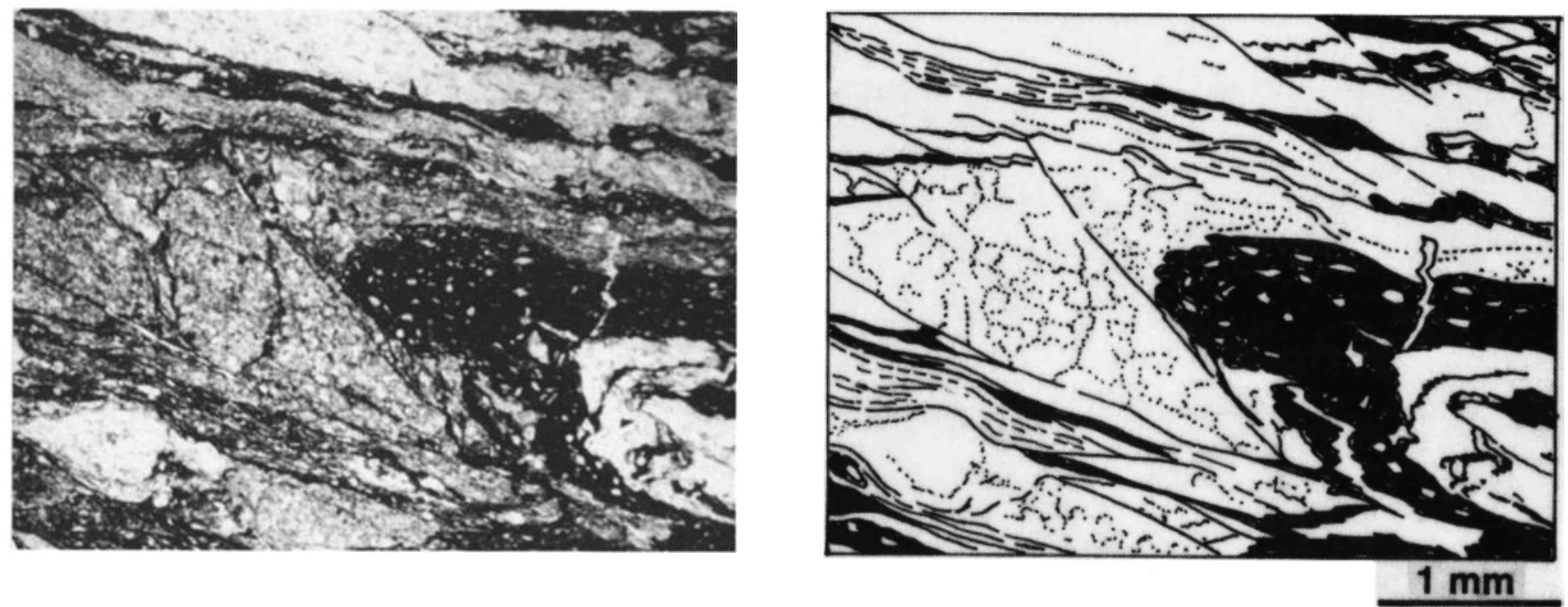

Fig. 10b. Photomicrograph of Sample VE 12-4 $(5138 \mathrm{~m})$ : deformed, mafic, layered sandstone from a fault gauge on the southerm flank of the median ridge. The rock is composed of alternating layers, 1-mm thick, showing isoclinal folds and small scale shear bands. The dark (red) layers contain hematite grains and small fragments of chlorite, epidote and actinolite whereas light (green) layers contain detrital pyroxenes and needles of green amphibole in a chlorite-rich matrix. No fresh plagioclases have been observed (plane polarized light).
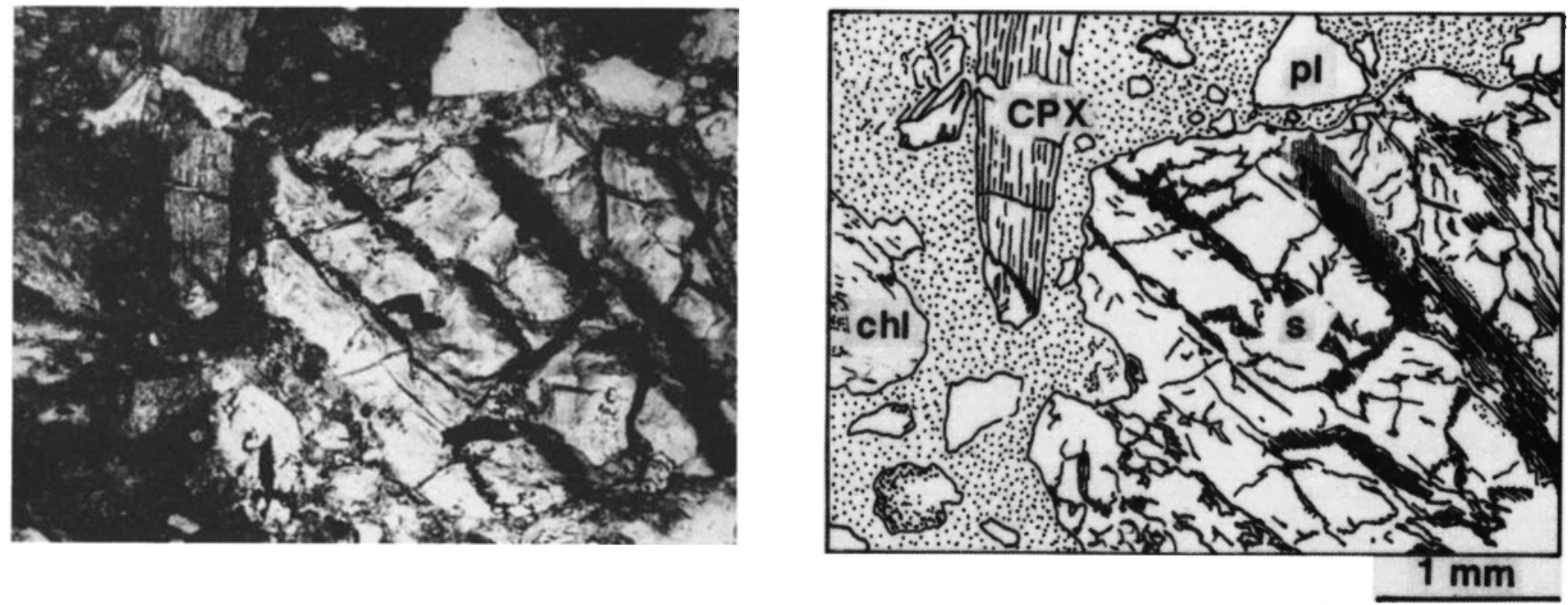

Fig. 10c. Photomicrograph of Sample VE 12-6 (4873 m): greenschist facies gabbro breccia containing rounded clasts of greenschist metagabbro in a matrix of gabbroic sandstone with fragments of clinopyroxenes (CPX), altered plagioclases (pl), green amphiboles and chlorite (chl). A large serpentinite fragment (s) is present in the central part of the photograph (plane polarized light). 

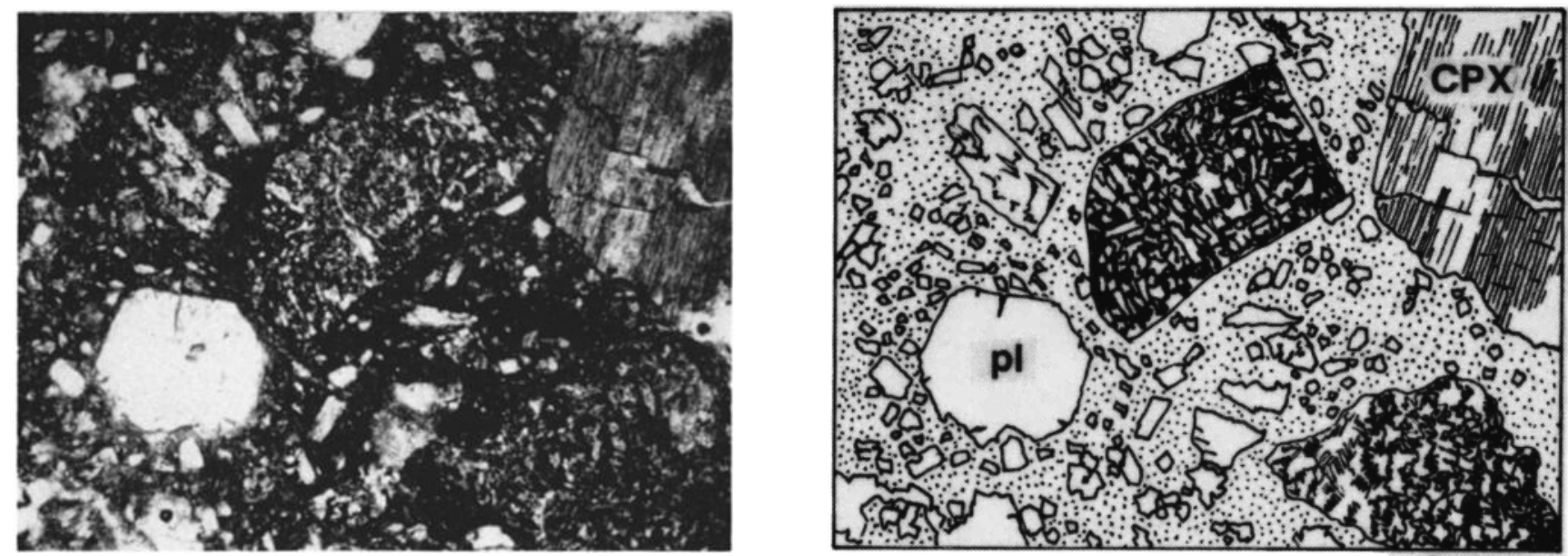

$1 \mathrm{~mm}$

Fig. 10d. Photomicrograph of Sample VE 12-10 $(3832 \mathrm{~m})$ : greenschist mafic polymictic breccia with metagabbro, metadolerite and metabasalt fragments. Isolated detrital minerals such as pyroxenes (CPX), amphiboles and plagioclases (pl) are abundant within the fine-grained, mafic matrix. Clasts are matrix-supported (plane polarized light).
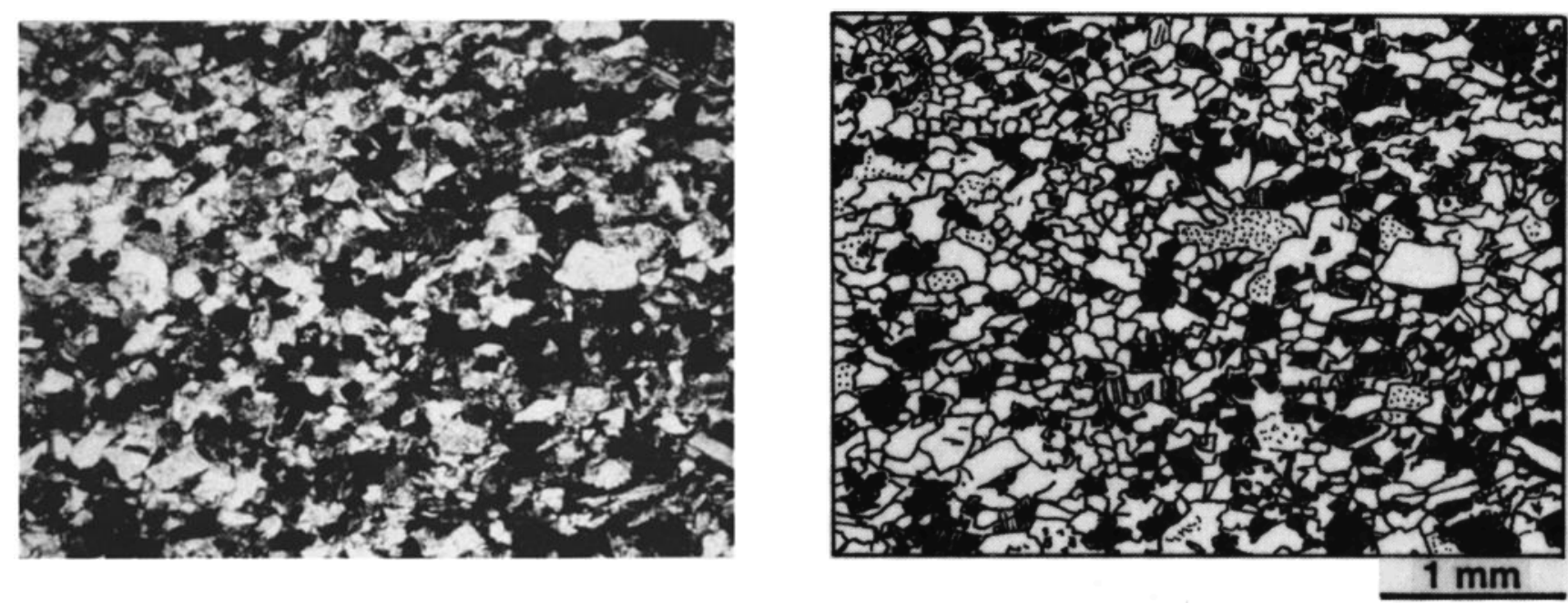

Fig. 10e. Photomicrograph of Sample VE 10-1 $(4810 \mathrm{~m})$ : hematite rich, mafic, graded-bedded sandstone. The rock consists of millimeter sized lithic clasts of more or less altered basalts, dolerites and weathered basaltic glass and smaller fragments of isolated minerals (plagioclases, pyroxenes, amphibolitized pyroxenes, chlorites, amphiboles). Abundant hematite grains give the dark-red color to this rock. Micrite grains are present locally (plane polarized light).
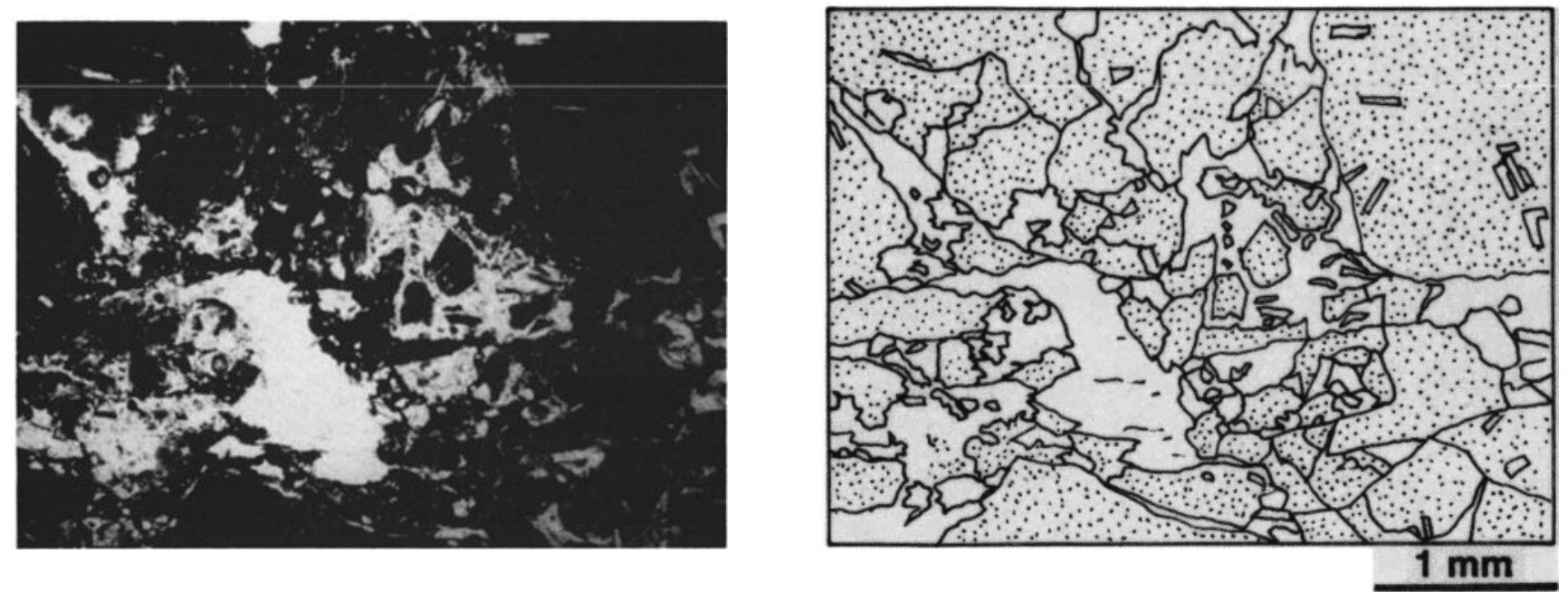

Fig. 10f. Photomicrograph of Sample VE $12-7$ (4661 m): monomictic pillow breccia. The dark color of the basaltic clast is mainly due to development of hematite. The glassy matrix of the breccia is now replaced by chlorite (plane polarized light). 


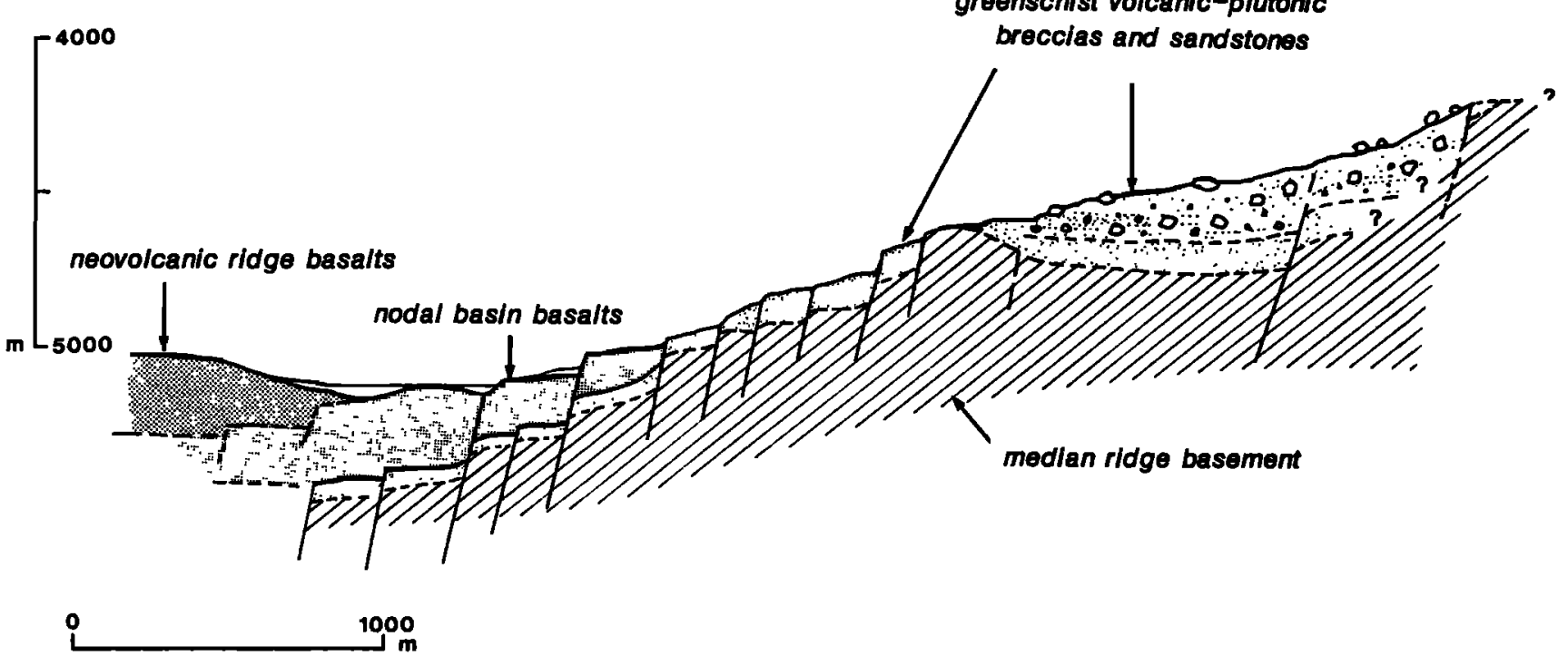

Fig. 11. Synthetic N-S geological section of the southem flank of the median ridge of the FZ at the tip of the MAR axis, at $40^{\circ} 53^{\prime} \mathrm{W}$ along track of dive 17.

Assuming that gabbros and dykes are large blocks within a detrital formation, and that the basalts represent basement outcrops, the median ridge can be regarded as a portion of relatively undisrupted oceanic lithosphere covered with a thick sequence of coarse to fine-grained detrital formations, as represented in Figure 7. The nature of the rocks sampled from the western extension of the median ridge, i.e., the "Vema mound" at about $41^{\circ} 50^{\prime} \mathrm{W}$, is consistent with this interpretation.

The median ridge is now linked to the African Plate, since it is located to the north of the PDDZ. If we assume that the transform fault zone (TFZ, as defined by Fox and Gallo [1984]) always remained south of the median ridge, the crust of the ridge was created at the western RTI. In this case, the northem trough of the valley should be considered only as the northem tectonic limit of the uplifted median ridge and not as the topographic expression of a fossil transform-related fault.

Alternatively, it is possible that the TFZ jumped to different successive positions within the fracture valley, from one edge of the fracture to the other. In such conditions, the median ridge basement should be regarded as the tectonic juxtaposition of vertical slices of oceanic crust created nonpreferentially at the western or eastern RTIs, and separated by fossil traces of the successive TFZs. This hypothesis is consistent with geophysical data obtained at the western part of the Vema transform where the crust of the fracture valley has been shown to have an anomalous structure interpreted as resulting from intense fracturing and tectonic brecciation [Detrick et al., 1982].

One can also imagine that dip-slip normal or reverse fossil faults related to previous nontransform-related tectonic events such as the uplift of the transverse ridge crosscut the basement of the median ridge.

\subsection{The Geological Boundaries of the Median Ridge}

Dive observations and sample analysis lead us to define the southern geological limit of the median ridge as the boundary between the polymictic detrital formations exposed on the southern flank of the ridge, and the recent volcanics outcropping along the southern transform trough. To the north of the nodal basin, this boundary can be clearly defined as the northernmost extension of fresh volcanics. This geological boundary coincides with the PDDZ only in the westernmost part of the surveyed area, to the west of $40^{\circ} 56 \mathrm{~W}$ (Figure 4). Between $40^{\circ} 56^{\prime} \mathrm{W}$ and $40^{\circ} 54^{\prime} \mathrm{W}$, in the area of dives 8 and 18 , this boundary diverges from the PDDZ, and trends NE, roughly parallel to the $4800 \mathrm{~m}$ isobath. Farther east of $40^{\circ} 54^{\prime} \mathrm{W}$, the boundary runs approximatively E-W, following the $5000 \mathrm{~m}$ isobath. It appears finally that the northernmost extension of the neovolcanic zone is now linked to the northern (Africa) Plate.

\subsection{The Hematile-Rich Breccias From the Southern Flank of the Median Ridge}

Metabasaltic breccias with hematitic cement were collected during dives $8,9,10,11,12,17$ and 18 from the lower slopes of the southern flank of the median ridge (Figures 4,10 and 12). These breccias are made up of subangular to sub-rounded rock and mineral fragments from various parts of pillow lavas, and from the inner part of thick flows or dykes. They do not include gabbro or serpentine fragments and therefore differ from the polymictic breccias recovered along the northern flank of the median ridge.

The nature of the cement has been determined by $X$ ray diffraction analysis. It consists of a mixture of clay minerals and hematite which gives a dark red color to the collected breccias. The basaltic elements have undergone various alterations which demonstrate the polygenic character of the breccias. For instance, the microlitic basalt fragments sometimes display centripetal color zonation with light colored margins around dark cores indicating that the rock fragments were altered after or while being deposited. Basaltic minerals, except augite, are generally partly altered, e.g., plagioclases, or completely replaced, e.g., olivine, by relatively low temperature secondary minerals such as clay minerals, chlorite, actinolite or zeolites. The basaltic elements may include epidote veinlets but the whole rock samples are criss-crossed by later zeolite veins. These observations 


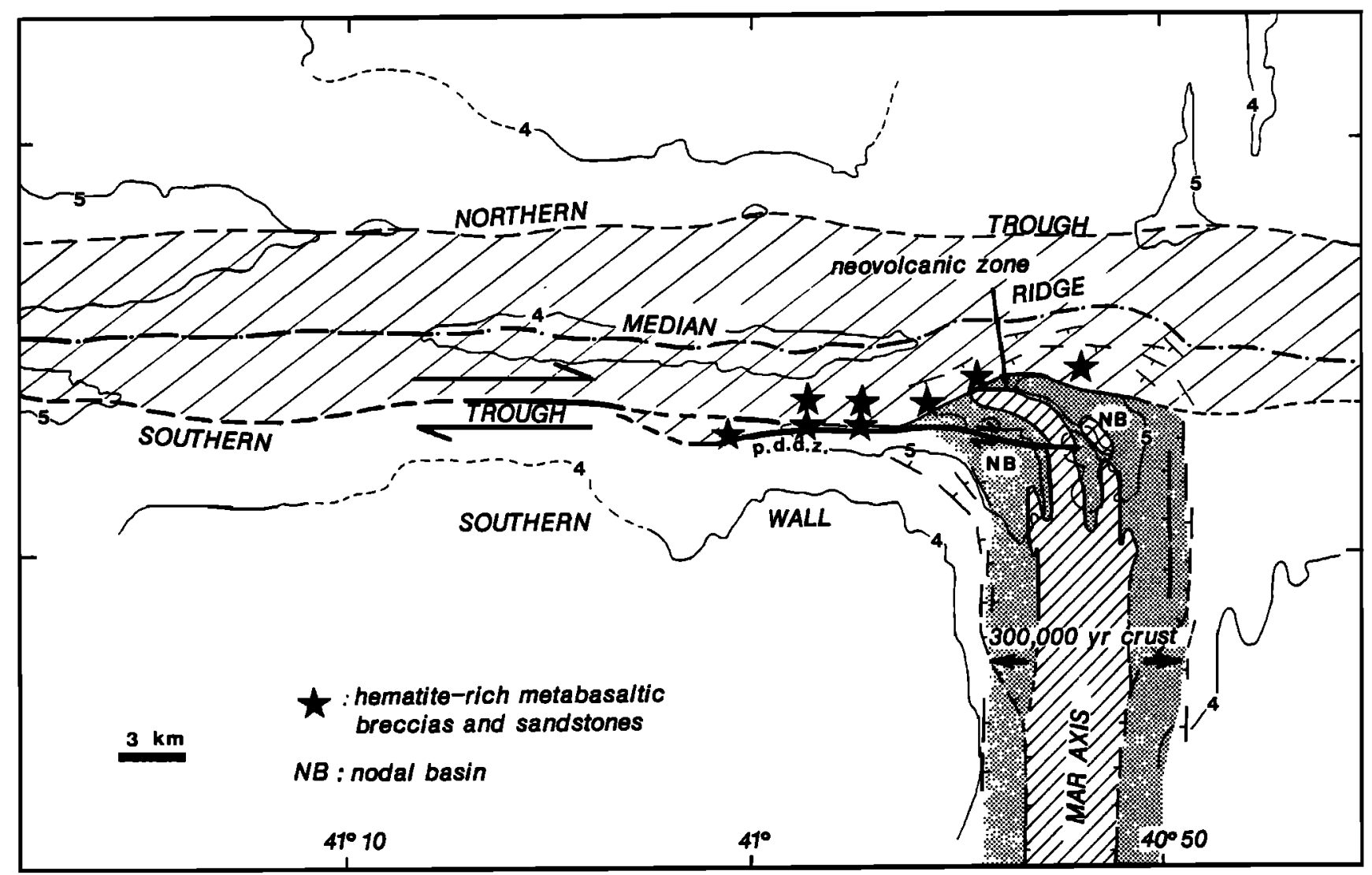

Fig. 12. Simplified structural map of the eastern part of the Vema transform fault and its intersection with the MAR axis, and location of sites where hematite-rich metabasaltic sandstones and breccias have been sampled during the Nautile dives. Crust created during the last 300,000 years (according to a $3.2 \mathrm{~cm} / \mathrm{yr}$ spreading rate) is indicated.

suggest a polymetamorphic evolution of the breccias and their elements. Hematite is observed as opaque infillings of fissures through the rock fragments or as thin light coatings of cracks and cleavages within plagioclases and augite phenocrysts. Hematite also coats and fills in microfossils such as foraminiferas and radiolarians in the matrix of the breccias. The monogenic composition of the breccias and their location in a restricted belt along the tectonized, southern flank of the median ridge suggest that they originated from the basaltic basement of the median ridge. Therefore, occurrence of this type of breccia can be interpreted as exposure of the median ridge basement.

In summary, this preliminary study of basaltic breccias with hematitic cement collected along the southern flank of the median ridge indicates a multistage evolution comprising (1) the transportation of already altered basaltic fragments, including pillow lavas and dolerites; (2) their cementation by clay minerals and hematite and additional alteration by Fe-rich solutions; (3) their in situ deformation, along subvertical strike-slip or dip-slip faults related to transcurrent movements along the fracture zone and/or to vertical movements on the edges of the nodal basin. Development of hematite results from low temperature $\left(<100^{\circ} \mathrm{C}\right)$ hydrothermal circulations probably indicating the presence of deep active crustal fractures. Occurrence of iron-rich basaltic breccias is an additional indication that the southem boundary of the Vema median ridge is (west of $40^{\circ} 56^{\prime} \mathrm{W}$ ), or has been (east of $40^{\circ} 56^{\prime} \mathrm{W}$ ), tectonically controlled by faulting (Figure 12) .

Similar deposits have been observed in active submarine volcanoes such as Banu Wuhu, Indonesia [Zelenov, 1964];
Stromboli or Santorini, Mediterranean Sea [Bonatti and Honnorez, 1972; Puchelt, 1973]. Hematite-cemented basaltic breccias have also been recovered from Cretaceous central Pacific seamounts where oxygen isotope analysis of hematite indicates temperatures ranging from $30^{\circ}$ to $90^{\circ} \mathrm{C}$ for formation of the cement (J. Hein and H.W. Yeh, personal communication, 1990). Mafic-ultramafic breccias with red, hematitic cement are also abundant in ophiolites where evidences of oceanic tectonism are present. In the ligurian ophiolites of the northern Apennines polymictict breccias with gabbro fragments and subordinate basaltic debris are cemented by chlorite, with hematite and minor carbonates [Gianelli and Principi, 1974; Barret and Spooner, 1977]. Some of these breccias rest stratigraphically over serpentinized mantle and ophicalcites and are conformably overlain by pillow basalts. Occurrence of numerous epidote veins indicates that hydrothermal circulation took place within the breccia. Locally, doleritic dykes cut through the breccias. Mafic breccias with iron-rich cement and hematitic, red sandstones are also present in Cyprus, within the Arakapas fault belt which is thought to represent a fossil transform fault [Simonian and Gass, 1978].

\subsection{Structural Results and Implications}

Two striated, almost vertical fault planes were observed on the southern median ridge's flank: one at $40^{\circ} 59^{\prime} \mathrm{W}$ (dive 12) strikes a N140 direction and exhibits striations with a moderate pitch to the south $\left(0^{\circ}\right.$ to $\left.20^{\circ}\right)$, the other one, at $40^{\circ} 51^{\prime} \mathrm{W}$ (dive 17), trends N90-110 and shows striations with a $30-40^{\circ}$ westward pitch. The geometry of the striations indicates that 
these faults accommodated a combination of strike-slip and vertical displacements.

Dives 18 and 17 clearly show that volcanics from the MAR neovolcanic zone have erupted far to the north of the PDDZ, and have partly covered the southern flank of the median ridge. The median ridge has an arcuate shape in this area, and is less elevated and narrower than further to the west (Figure 2). This arcuate shape was first tentatively interpreted as a result of the northward propagation of the MAR neovolcanic segment causing the bending of the median ridge and local compression [Auzende et al., 1989]. The reduced width and elevation of the ridge in the RTI area suggest, however, an alternative explanation: we propose that the southem part of the median ridge in the intersection domain has undergone subsidence during the deepening of the nodal basin (Figure 3), prior to the eruption of the lavas which form the floor of the nodal basin and the neovolcanic ridge.

\section{General Discussion and Conclusions}

\subsection{Origin of the Median Ridge Detrital Cover Formation}

Considerable volumes of mafic and ultramafic breccias are currently being deposited in tectonically active regions of the ocean floor. Thick detrital formations containing mafic and ultramafic fragments have been observed and studied in detail on the flanks of the Gorringe bank in the Atlantic [Lagabrielle and Auzende, 1982], in elongated basins of the Clipperton fracture zone [Barany and Karson, 1989], at the foot of the northern wall of the Blanco trough ( $T$. Juteau, personal communication, 1991), and in other low- or fast-slipping transform faults : Romanche FZ [Bonatti et al., 1974; Bonatti and Honnorez, 1976]; Atlantis FZ [Dick et al., 1991]; Garret FZ [Hébert et al., 1983], etc. As emphazised by Barany and Karson [1989], this confirms that wrench tectonics and vertical movements of crustal blocks are the two main processes causing disaggregation of the oceanic basement and gravity movements of debris. Such processes are both active in transform fault settings.

The nature of the clasts recovered from the detrital cover formation of the Vema median ridge suggests that the breccias originated from the disaggregation of outcrops of various levels of oceanic crust and of upper mantle-derived peridotites. Dredging and diving results show that all these rocks are frequently exposed along both walls of the Vema Fracture Zone [Bonatti and Honnorez, 1971; Melson and Thompson, 1971; Thompson and Melson, 1972; Bonatti et al., 1974; Bonatti and Honnorez, 1976; Prinz et al., 1976; Honnorez et al., 1984; Mével, 1981; Auzende et al., 1989, 1990]. Diving studies, however, also suggest that these walls are not currently affected by active mass wasting: serpentinites, gabbros and basalts exposed along the north wall of the fracture zone explored during Nautile dive 14 at $41^{\circ} \mathrm{W}$, are covered by a thick manganese crust. Moreover, the gabbros observed along the north flank of the transverse ridge around $42^{\circ} 42 \mathrm{~W}$ (Nautile dives 1 to 5 [Auzende et al., 1989; Cannat et al., 1991]) are conformably covered by pelagic sediments which yielded fossils ranging from Miocene to Pleistocene in age [Aubry et al., 1992]. We therefore propose that extensive disaggregation of deep crustal and upper mantle outcrops, and emplacement of the detritus in the median valley of the fracture zone, are not present-day processes but occurred mostly during a previous tectonic episode, involving significant uplift of one or both fracture valley walls. An important uplift episode is known to have affected the southem wall of the transform valley, resulting in the creation of the transverse ridge. Paleontological data suggest that this event may have occurred some 10 m.y. ago [Bonatti and Honnorez, 1971; Honnorez et al., 1975; Bonatti et al., 1983]. Bonatti and Crane [1982] suggested that this event might have been related to a contemporaneous change in plate motion in the central Atlantic [Van Andel et al., 1971; Roest and Collette, 1986]. Hence, we propose that the detrital cover of the Vema median ridge might represent the sedimentary record of the transverse ridge uplift (Figure 13). Since this uplift episode, the transverse ridge and the detritus-covered transform valley floor, separated by the transform fault zone, would have migrated westward and eastward respectively (Figure 13). This model assumes that no significant migration of the transform fault took place since about $10 \mathrm{~m} . y$. ago. The $1.5 \mathrm{~km}$ thick ponded turbidites of Pleistocene age that constitute the sedimentary infill of the central part of the valley are thought to have buried the rough topography inherited from these complex tectonic and sedimentary events.

\subsection{Uplift of the Median Ridge Near the RTI Domain}

The mafic detrital formations exposed along the median ridge crest culminate at about $1000 \mathrm{~m}$ above the floor of the transform valley. It seems unlikely that the deposition of a thick horizontally layered detrital cover would have been possible on such a topographic high. Consequently, we conclude that the median ridge is currently being uplifted from the transform valley floor. This conclusion is confirmed by seismic data obtained near the eastern RTI (refer to profile B, Figure 5 from Eittreim and Ewing [1975], and Deep Tow's 4$\mathrm{kHz}$ seismic profiles by Kastens et al. [1986]) showing evidence for vertical tectonics in the sedimentary infill of the transform valley. According to the latter authors, the Vema median ridge may be a recent topographic feature, whose western tip is currently being uplifted at rates possibly as high as $1 \mathrm{~mm} / \mathrm{yr}$.

Our data provide further constraints to the mechanism of this uplift. Submersible observations demonstrate that the northem flank of the ridge suffered no recent deformation and that the very recent tectonic activity is only concentrated on the southern flank and at the summit of the median ridge, where basement rocks are exposed. This suggests that, at least in the surveyed area, the uplift of the median ridge is accompanied by a progressive tilting. As shown by results of dive 14, the northern wall of the fracture valley is capped by a very thick manganese crust and is tectonically inactive (Figure 9a) indicating that the tectonic activity related to the rejuvenation of the median ridge has been essentially restricted to the southern part of the fracture valley [Auzende et al., 1989].

Several possible mechanisms may account for the uplift of the Vema median ridge near the eastem RTI. Two of these mechanisms are discussed here: (1) serpentinization of the upper mantle beneath the median ridge; and (2) return of the transform valley to isostatic equilibrium, following reheating of the old plate near the tip of the eastern MAR segment. The second model suggests a direct relationship between RTI processes and the development of a median ridge in the transform valley.

1. Serpentinization of peridotites involves up to $30-40 \%$ expansion [Thayer, 1966; Page, 1967; Nicolas, 1969; Coleman, 1971; Komor et al., 1985] and a correlative density 


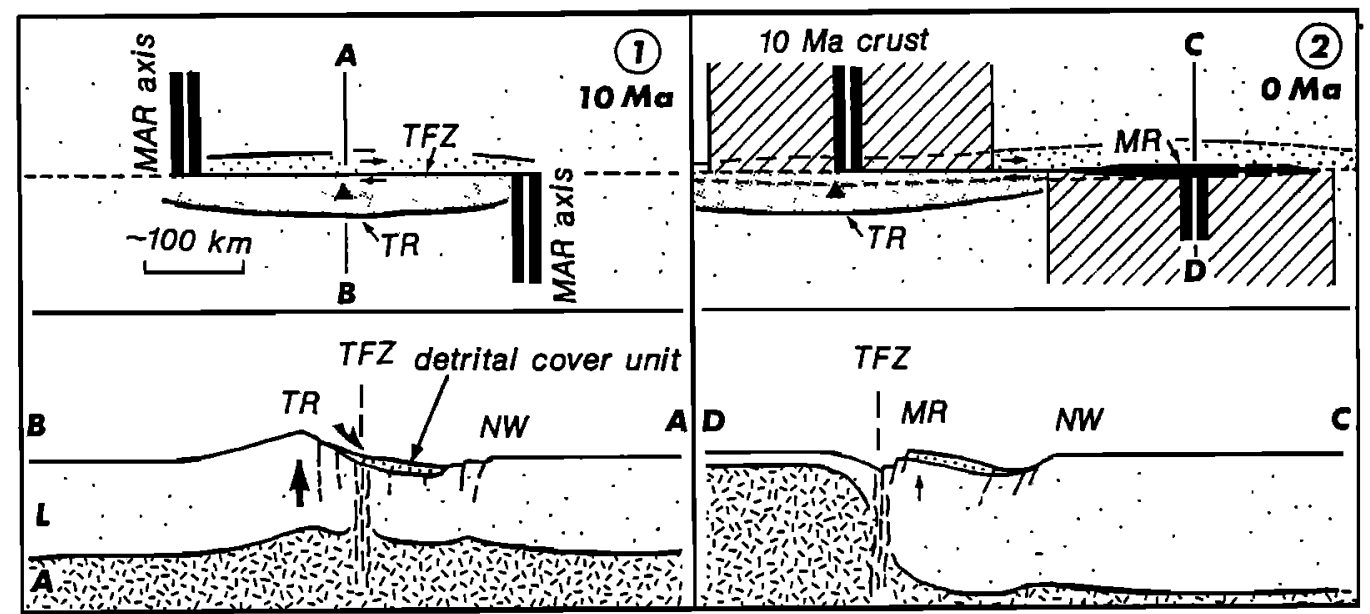

Fig. 13. A speculative model for the evolution of the Vema median ridge between 10 and 0 m.y. Panel 1 depicts the situation $10 \mathrm{~m} . y$. ago. The transverse ridge is being uplifted; the detrital cover is emplaced in the transform valley. Panel 2 depicts the present-day situation. The transverse ridge and the valley floor migrate westward and eastward respectively. The crust in the eastemmost portion of the active transform valley undergoes uplift near the tip of the MAR axis resulting in the partial exposure of the detrital cover formation and the median ridge basement. Thickness of the median ridge detrital cover has been considerably enlarged. Note the strong vertical exaggeration in lower cartoons. TR: transverse ridge; NW northem wall; MR: median ridge; TFZ: transform fault zone.

and seismic velocity decrease [Christensen, 1972]. Extensive hydrothermal alteration of the upper mantle in the transform domain may therefore cause uplift through two mechanisms: overpressure resulting from volume increase; and serpentinite diapirism resulting from the density contrast between the serpentinites and the surrounding upper mantle and lower crustal rocks. Nautile dive observations show that the Vema FZ median ridge is not composed of large volumes of serpentinite. Basement exposures are made up of basalts or possibly of gabbros, and serpentinite clasts are relatively rare in the detrital cover. Our observations do not preclude, however, extensive serpentinization of the mantle beneath the ridge, which may cause uplift from the density contrast. Because hydration of the upper mantle in the transform domain may be an ongoing process, it could cause the inferred present-day uplift of the western part of the median ridge [Kastens et al., 1986]. However, we may ask why median ridges are not present in all large transforms, and why do these ridges, when present, often develop only in one part of the transform valley? A possible answer to these questions is, as pointed out by Dick et al. [1991] in the case of the Atlantis II FZ, that hydrothermal alteration of the upper mantle may be enhanced in portions of transform valley lithosphere that have experienced thinning, or extensive slicing, during phases of tectonic reorganization of the transform domain. This answer remains, however, not entirely satisfying in the case of the Vema FZ, because seismic experiments in the western part of the transform valley, where no bathymetric median ridge exists, suggest extensive hydrothermal alteration of the crust and upper mantle [Detrick et al., 1982]. Other major transform valleys with no bathymetric median ridges also have anomalous seismic crustal structures, suggesting extensive hydration and serpentinization [White et al., 1984; Calvert and Potts, 1985]. On the other hand, peridotites recovered from the median ridge of the Doldrums FZ are relatively unserpentinized [Bonatti et al., 1992]. It appears that extensive serpentinization of the upper mantle is probably not by itself sufficient to cause the formation of a median ridge in the transform valley.
2. Detrick et al. [1982] proposed that the Vema transform valley floor lies more than $1 \mathrm{~km}$ deeper than its isostatic equilibrium depth calculated with respect to a normal oceanic crustal section. This interpretation is based on modeling of the crustal structure from seismic experiments in the western part of the Vema transform valley. They further propose that isostatic rebound of the valley floor is probably prevented by the rigidity of the cooling lithosphere. We propose that reheating of this lithosphere as it approaches the opposite ridge segment [Forsyth and Wilson, 1984; Phipps Morgan and Forsyth, 1988] should lower this rigidity and allow this isostatic rebound to occur. In addition, reheating of old cold lithosphere as it approaches the RTI should cause thermal expansion and consequently an uplift which could be as large as several hundred meters [Louden and Forsyth, 1976; Bonatti, 1978; Forsyth and Wilson, 1984]. In this hypothesis, the Vema median ridge would represent a portion of the transform valley floor, attached to the African Plate, that underwent recent uplift in the westem RTI domain. According to Detrick et al.'s [1982] calculations, the $3900 \mathrm{~m}$ average depth of the crest of the median ridge between $40^{\circ} 56.7^{\prime} \mathrm{W}$ and $41^{\circ} 07.3^{\prime} \mathrm{W}$ corresponds to isostatic equilibrium, implying that the deep structure of the ridge is similar to that modeled further west for the transform valley floor. The lower elevation and narrow, arcuate shape of the median ridge east of $40^{\circ} 57^{\circ} \mathrm{W}$ is inferred to have resulted from tectonic extension during the subsidence of the nodal basin. This may explain why the highest elevation of the median ridge is not found at the tip of the MAR axis.

A steady state process could simply explain the isostatic rebound, assuming that reheating and softening of the edge of the African plate are constant processes. Isostatic rebound of the median ridge is assumed to start some $50-55 \mathrm{~km}$ to the west of the MAR segment where the median ridge emerges from the sedimentary infill of the fracture valley at $5000 \mathrm{~m}$ (Figure 2). The equilibrium depth of $3900 \mathrm{~m}$ is reached about $25 \mathrm{~km}$ east of the western tip of the ridge. Given an average half slip rate of $16 \mathrm{~mm} / \mathrm{yr}$, this equilibrium depth is reached after $1.5 \mathrm{Ma}$. This corresponds to an uplift rate of the order of 0.5 to $1 \mathrm{~mm} / \mathrm{yr}$. 


\subsection{A Model of the Recent Tectonomagmatic Evolution of the Eastern RTI Domain}

Dives 18 and 17 clearly show that relatively fresh volcanics from the MAR neovolcanic zone have erupted far to the north of the PDDZ, up to the foot of the southern flank of the median ridge. Therefore, for a recent period, the RTI was characterized by a pulse of extensive volcanic activity. Furthermore, a phase of local extension occurred probably prior to or during the lava emplacement resulting in the subsidence of the southern flank of the median ridge and in the retreat of the crest of the median ridge to the north of its previous position. Consequently, the basement of the median ridge is thought to underlie the volcanics of the northern part of the nodal basin, as shown on a synthetic crosssection (Figure 11). The arcuate shape of the median ridge crest was created at that time.

The $9 \mathrm{~km}$ width of the rift valley $10 \mathrm{~km}$ south of the nodal basin is defined by the distance between the $4000 \mathrm{~m}$ isobath of both walls of the valley (Figure 12). Given a spreading rate of
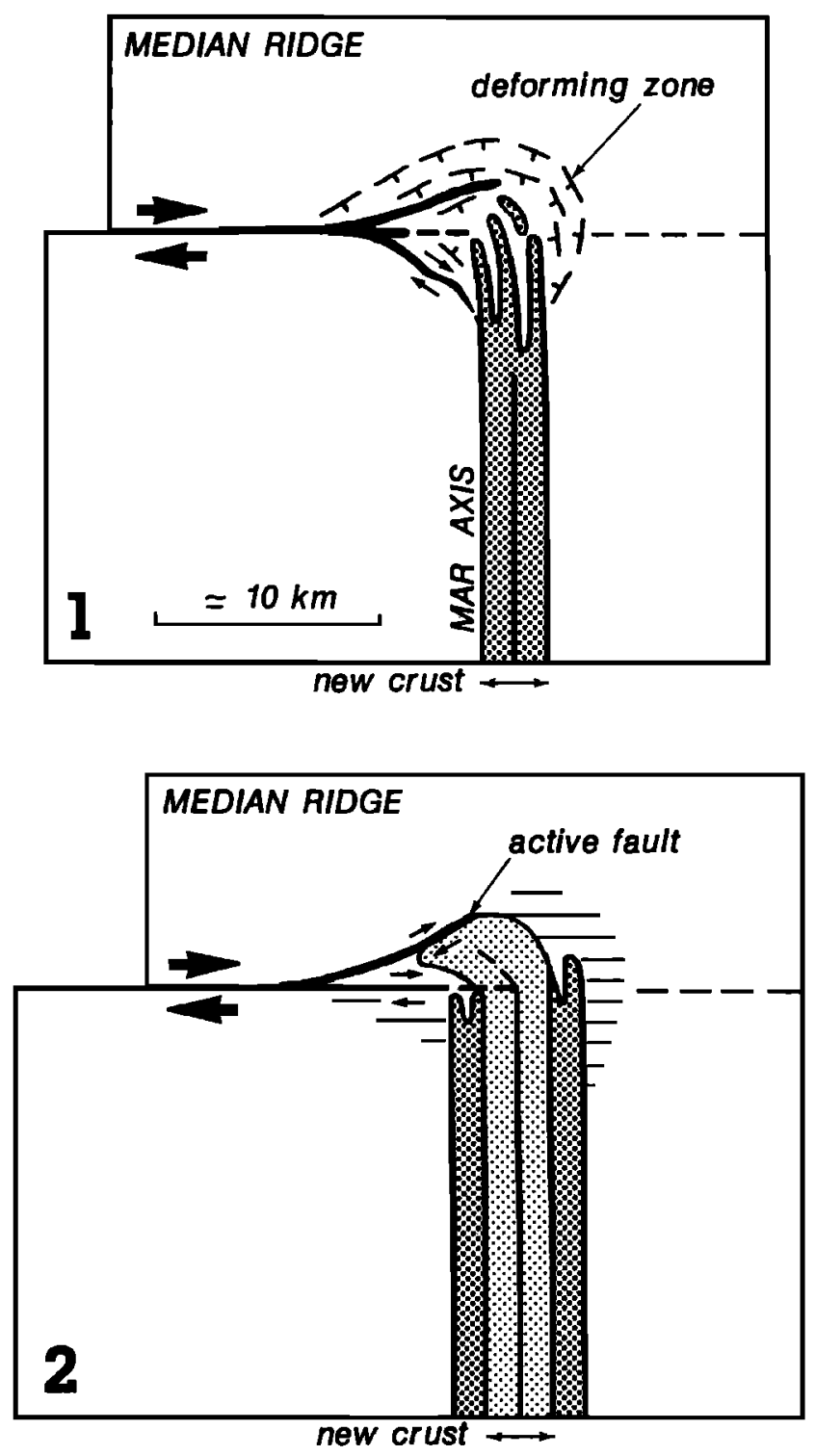

$32 \mathrm{~mm} / \mathrm{yr}$ as proposed by Cande et al. [1988], we may consider that the rift valley floor has been created during the last 300,000 years. This may be also the age of the volcanic basement of the nodal basin north of the present-day displacement zone (Figure 12).

According to the results presented above, we may define several stages in the very recent tectonic-volcanic history of the eastern RTI, that is, roughly during the last 300,000 years (Figure 14). These stages which involve alternatively tectonic or magmatic processes are almost continuous and probably overlap each other. At this scale of time, it is not possible to define precisely the duration of each process involved.

Stage 1 . The RTI is characterized by an extensional regime and a low magma supply. It is now suggested that in periods of restricted magmatic activity, the deforming zones at RTI's are broader than during periods of high magma supply [Karson and Dick, 1983; Fox and Gallo, 1984; OTTER Team, 1984; Macdonald et al., 1986; Harper, 1985; Pockalny et al., 1988;
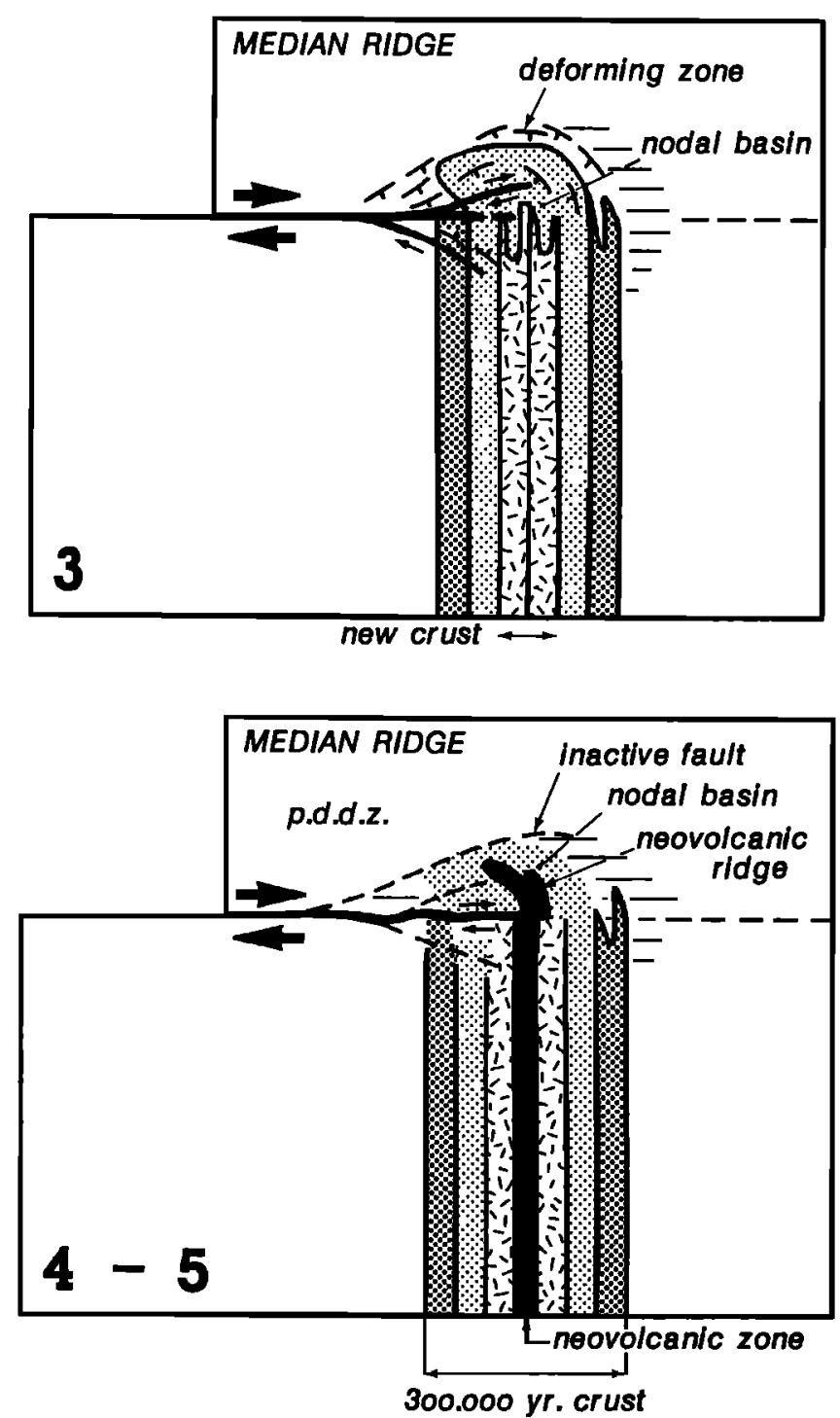

Fig. 14. A model for the evolution of the Vema eastem RTI during the last 300,000 years. The five successive stages are described in detail in the text. 
Allerton, 1989]. As a consequence of crustal stretching, the flank of the median ridge located immediately to the north of the ridge axis will suffer local subsidence. The arcuate shape of the crest of the median ridge could be partly inherited from this event.

Stage 2. Extension in the RTI domain during stage 1 was immediately followed by extrusion of abundant lava flows emplaced both along the MAR axis and on the collapsed south flank of the median ridge. Most of the present-day nodal basin floor was created during this high magma supply stage. The relatively fresh basalts observed during the end of dive 17 to the north of the eastern nodal basin (Figure 6) were probably erupted during this period. The deforming zone was narrower and progressively migrated farther north. Consequently, one of the main branches of the displacement zone may have crosscut the southernmost edge of the median ridge. The major fault marking the geological boundary between the median ridge formations and the neovolcanic products erupted in the RTI domain was the site of hydrothermal circulation. The mafic breccias with hematite and iron oxides sampled along this now inactive boundary are the remnants of this activity.

Stage 3. The volcanic activity decreased and the RTI was subjected to renewed amagmatic stretching. The final morphology that characterizes the present-day nodal basin is assumed to have been created during this stage. The deforming zone broadened and a large set of normal and strike-slip faults were active within the entire RTI domain. One of the main faults of this set, now inactive, runs probably along the northem boundary of the nodal basin.

Stage 4. Subsequent volcanic extrusions restricted to the center of the RTI domain occurred forming the neovolcanic ridge which crosscuts the nodal basin. Volcanics were extruded to the north of the present-day displacement zone up to the foot of the median ridge. The relatively fresh basalts observed on the flank of a conical edifice at the northern tip of the neovolcanic zone during dive 18 were probably emplaced during this period. The deforming zone became progressively more restricted.

Stage 5. The last stage corresponds to the present-day situation. The deforming zone is now restricted to a narrow fault belt which crosscuts the nodal basins and the neovolcanic ridge.

Acknowledgments. The authors are grateful to PJ. Fox and two anonymous referees for critical reviews of this paper and very valuable suggestions. The Vemanaute team is also grateful to the captain, officers and the crew of the R/V Nadir and to the technical team of the submersible Nautile. All of them allowed geological observations and sampling in very good conditons. We thank J.L. Travers for his help in preparing the photographs.

\section{REFERENCES}

Allerton, S., Distortions, rotations and crustal thinning at ridgetransform intersections. Nature, 340, 626-628, 1989.

Aubry, M. P., W.A. Berggren, A. Schaaf, J.-M. Auzende, Y. Lagabrielle, and V. Mamaloukas-Frangoulis, Paleontological evidence for early exposure of deep crust on the Vema Fracture Zone southem wall, Mar. Geol., in press, 1992.

Auzende, J.M., D. Bideau, E. Bonatti, M. Cannat, J. Honnorez, Y. Lagabrielle, J. Malavieille, V. Mamaloukas-Frangoulis, and $C$. Mével, Une coupe complète de la croûte océanique sur le mur sud de la zone de fracture Vema (Atlantique central): Résultats préliminaires de la campagne Vemanaute, C. R. Acad. Sci., Ser. 2, 307, 2061-2067, 1988.

Auzende, J.M., D. Bideau, E. Bonatti, M. Cannat, J. Honnorez, Y. Lagabrielle, J. Malavieille, V. Mamaloukas-Frangoulis, and C.
Mével, Direct observation of a section through slow-spreading oceanic crust. Nature, 337 (6209), 726-729, 1989.

Auzende, J.M., D. Bideau, E. Bonatti, M. Cannat, J. Honnorez, Y. Lagabrielle, J. Malavieille, V. Mamaloukas-Frangoulis, and C. Mével, The MAR-Vema fracture zone intersection surveyed by deep submersible Nautile, Terra Nova, 2, 68-73, 1990.

Bader, R.G., et al., Site 26, Initial Rep. Deep Sea Drill. Proj., 4, 77. 92, 1970.

Barany, I., and J.A. Karson, Basaltic breccias of the Clipperton fracture zone (east Pacific): Sedimentation and tectonics in a fastslipping oceanic transform, Geol. Soc. Am. Bull., 101, 204-220, 1989.

Barret, T.J., and E.T.C. Spooner, Ophiolitic breccias associated with allochtonous oceanic crustal rocks in the east ligurian Apennines, Italy: A comparison with observations from rifted oceanic ridges, Earth Planet. Sci. Lett., 35, 79-91, 1977.

Bonatti, E., Vertical tectonism in oceanic fracture zones, Earth Planet. Sci. Lett., 37, 369-379, 1978.

Bonatti, E., and K. Crane, Oscillatory spreading explanation of anomalously old uplifted crust near oceanic transforms, Nature, 300 (5890), 343-345, 1982.

Bonatti, E., and J. Honnorez, Non-spreading crustal blocks at the MAR, Science, 174, 1329-1331, 1971.

Bonatti, E., and J. Honnorez, Submarine iron deposits from the Mediterranean Sea, in The Mediserramean Sea, edited by D.J. Stanley, pp. 701-710, Dowden, Hutchinson and Ross, Stroudsburg, Pa., 1972.

Bonatti, E., and J. Honnorez, Sections of the Earth's crust in the equatorial Atlantic, J. Geophys. Res., 81, 4104-4116, 1976.

Bonatti, E., C. Emiliani, G. Ferrara, J. Honnorez, and H. Rydell, Ultramafic carbonate breccias from the equatorial MAR, Mar. Geol., 17, 83-102, 1974.

Bonatti, E., R. Sartori, and A. Boersma, Vertical crustal movements at the Vema fracture zone in the Atlantic: Evidence from dredged limestones, Tectonophysics, 91, 213-232, 1983.

Bonatti, E., A. Peqve, P. Kepezhinskas, N. Kurentsora, M. Seyler, S. Skolotnev, and G. Udintsev, Upper mantle heterogeneity below the Mid-Atlantic Ridge, $0^{\circ}-15^{\circ} \mathrm{N}$, Earth Planet. Sci. Lett., in press, 1992.

Bowen, A.N., and R.S. White, Deep tow profiles from the Vems transform and RTI, J. Geol. Soc. London, 143, 807-817, 1986.

Calvert, A.J., and C.G. Potts, Seismic evidence for hydrothermally altered mantle beneath old crust in the Tydeman fracture zone, Earth Planet. Sci. Lett., 75, 433-449, 1985.

Cande, S.C. J.L. Labrecque, and W.F. Haxby, Plate kinematics of the South Atlantic: Chron C34 to present, J. Geophys. Res., 93(B11), 13479-13492, 1988.

Cannat, M., V. Mamaloukas-Frangoulis, J.M. Auzende, D. Bideau, E. Bonatti, J. Honnorez, Y. Lagabrielle, J. Malavieille, and C. Mével, A geological cross-section of the Vema fracture zone transverse ridge, J. Geodyn., 13, 97-118, 1991.

Christensen, N.I. The abundance of serpentinites in the oceanic crust, J. Geol., 80, 709-719, 1972.

Coleman, R.G., Petrologic and geophysical nature of serpentinites, Geol. Soc. Am. Bull., 82, 879-918, 1971.

Detrick, R.S., M.A. Cormier, R.A. Prince, and D.W. Forsyth, Seismic constraints on the crustal structure within the Vema fracture zone, $J$. Geophys. Res., 87, 10599-10612, 1982.

Dick, H.J.B., H. Schouten, P.S. Meyer, D.G. Gallo, H. Bergh, R. Tyce, P. Patriat, K.T.M. Johnson, J. Snow, and A. Fisher, Tectonic evolution of the Atlantis II fracture zone, Proc. Ocean Drill. Program Sci. Results, 118, 359-398, 1991.

Eittreim, S., and J. Ewing, Vema fracture zone transform fault. Geology, 3, 555-558, 1975.

Forsyth, D.W., and B. Wilson, Three-dimensional temperature structure of a ridge-transform-ridge system, Earth Planet. Sci. Lett., $70,355-362,1984$

Fox, P.J., and D.G. Gallo, A tectonic model for ridge-transform-ridge plate boundaries: Implications for the structure of oceanic lithosphere. Tectonophysics, 104, 205-242, 1984.

Gallo, D.G., P.J. Fox, and K.C. Macdonald, A Sea Beam investigation of the Clipperton transform fault: The morphotectonic expression of a fast slipping transform boundary, J. Geophys. Res., 91(B3), 3455-3467, 1986.

Gianelli, G., and G. Principi, Studies on mafic and ultramafic rocks, 1, Breccias of the ophiolite suite in the Monte Bocco area (Ligurian Apennine), Boll. Soc. Geol. It., 93, 277-310, 1974. 
Harper, G.D., Tectonics of slow spreading mid-ocean ridges and consequences of a variable depth to the brittle/ductile transition, Teclonics, 4, 395-409, 1985.

Hébert, R., D. Bideau, and R. Hekinian, Ultramafic and mafic rocks from the Garret transform fault near $13^{\circ} 30^{\prime} \mathrm{S}$ on the East Pacific Rise: Igneous petrology, Earth Planet. Sci. Letl., 65, 107-125, 1983.

Honnorez, J., E. Bonatti, C. Emiliani, P. Bonnimann, M.A. Furrer, and A.A. Meyerhoff, Mesozoic limestone from the Vema offset zone, Earth Planet. Sci. Lett., 26, 8-12, 1975.

Honnorez, J., C. Mével, and R. Montigny, Geotectonic significance of gneissic amphibolites from the Vema fracture zone, equatorial midAtlantic ridge, J. Geophys. Res., 89, 11379-11400, 1984.

Karson, J.A., and H.J.B. Dick, Tectonics of ridge-transform intersections at the Kane fracture zone. Mar. Geophys. Res., 6, 5198, 1983.

Kastens, K.A., K.C. Macdonald, and K. Becker, The Tamayo transform fault in the mouth of the Gulf of California, Mar. Geophys. Res., 4, 129-151, 1979.

Kastens, K.A., K.C. Macdonald, S.P. Miller, and P.J. Fox, Deep toy studies of the Verna fracture zone, 2, Evidence for tectonism an bottom currents in the sediments of the transform valley floor, $J$. Geophys. Res., 91, 3355-3367, 1986.

Komor, S.C., D.E. Elthon, and J.F. Casey, Serpentinization of cumulate ultramafic rocks from the North Amm Mountain massif of the Bay of Islands ophiolite, Geochim. Cosmochim. Acta, 46, 411421, 1985.

Lagabrielle Y., and J.M. Auzende, Active in situ disaggregation of oceanic crust and mantle on Gorringe Bank: Analogy with ophiolitic massives, Nature, 297, 490-493, 1982.

Louden, K.E., and D.W. Forsyth, Thermal conduction across fracture zones and the gravitational edge effect. J. Geophys. Res., 81, 4869 4874, 1976.

Louden, K.E., R.S. White, C.G. Potts, and D.W. Forsyth, Structure and seismotectonics of the Vema fracture zone, Atlantic Ocean, J. Geol. Soc. London, 143, 795-805.

Ludwig, W.J., and P.D. Rabinowitz, Structure of the Vema fracture zone, Mar. Geol., 35, 99-110, 1980.

Macdonald, K.C., K.A. Kastens, F.N. Spiess, and S.P. Miller, Deep tow survey of the Tamayo transform fault, Mar. Geophys. Res., 4, 37-70, 1979.

Macdonald, K.C., D.A. Castillo, S.P. Miller, P.J. Fox, K.A. Kastens, and E. Bonatti, Deep-tow studies of the Vema fracture zone, 1, Tectonics of a major slow slipping transform fault and its intersection with the Mid-Atlantic Ridge, J. Geophys. Res., 91(B3), 3334-3354, 1986

Mamaloukas-Frangoulis, V., J.-M. Auzende, D. Bideau, E. Bonatti, M. Cannat, J. Honnorez, Y. Lagabrielle, J. Malavieille, C. Mével, and H.D. Needham, In situ study of the eastem ridge-transform intersection of the Vema fracture zone. Tectonophysics, 190,55 $72,1991$.

Melson, W.G., and G. Thompson, Petrology of a transform fault and adjacent ridge sediments. Philos. Trans. R. Soc. London, ser. A, $268,423-441,1971$.

Mével, C., Occurrence of pumpellyite in hydrothermally altered basalts from the Vema fracture zone (Mid-Atlantic Ridge), Contrib. Mineral. Petrol., 76, 386-393, 1981.

Mével, C., J.-M. Auzende, M. Cannat, J.P. Donval, J. Dubois, Y. Fouquet, P. Gente, D. Grimaud, J.A. Karson, M. Segonzac, and M. Stievenard, La ride du Snake Pit (dorsale médio-Atlantique, $23^{\circ} 22^{\prime} \mathrm{N}$ ): Résultats préliminaires de la campagne Hydrosnake. $C$. $R$. Acad. Sci., ser. 2, 308, 545-552, 1989.

Mével, C., M. Cannat, P. Gente, E. Marion, J.-M. Auzende, J.A. Karson, Emplacement of deep rocks on the west median Valley wall of the MARK area, Teclonophysics, 190, 31-53, 1991.

Nicolas, A., Serpentinization d'une lherzolite: Bilan chimique, implication tectonique, Bull. Volcanol., 32, 499-508, 1969.

Oceanographer Tectonic Research Team (OTTER), The geology of the Oceanographer transform: The ridge-transform intersection, Mar. Geophys. Res., 6, 109-141, 1984.

Oceanographer Tectonic Research Team (OTTER), The geology of the Oceanographer transform: The Transform Domain, Mar. Geophys. Res., 7, 329-358, 1985.

Olivet, J.L., X. Le Pichon, S. Monti, and B. Sichler, Charlie Gibbs fracture zone, J. Geophys. Res., 79, 2059-2072, 1974.

Page, N.J., Serpentinization considered as a constant volume metasomatic process: a discussion, Amer. Mineral. 52, 545-550, 1967.
Perch-Nielsen, K., et al., Site 353 Vema fracture zone, Initial Rep. of the Deep Sea Drill. Proj., 39, 27-40, 1977.

Phipps Morgan, J., and D.W Forsyth, Three-Dimensional flow and temperature perturbations due to a transform offset: Effects on oceanic crustal and upper mantle structure, J. Geophys. Res. 93(B4), 2955-2966, 1988.

Pockalny, R.A., R.S. Detrick, and P.J. Fox, Morphology and tectonics of the Kane transform from Sea Beam bathymetry daca, J. Geophys. Res., 93(B4), 3179-3193, 1988.

Potts, C.G., R.S.,White, and K.E. Louden, Crustal structure of Atlantic fracture zones, II, The Vema fracture zone and transverse ridge, Geophys. J. R. Astron. Soc., 86, 491-513, 1986.

Prince, R.A., and D.W. Forsyth, Horizontal extent of anomalously thin crust near the Vema fracture zone from the three-dimensional analysis of gravity anomalies, J. Geophys. Res., 93(B7), 80518053, 1988.

Prinz, M., K. Keil, J.A. Green, A.M. Reid, E. Bonatti, and J. Honnorez, Ultramafic and mafic samples from the Equatorial MidAllantic Ridge and Fracture Zones, J. Geophys. Res., 81(23), 4087. 4103, 1976.

Puchelt, H., Recent iron sediment formation at the Kameni islands, Santorini (Greece), in Ores in Sediments, edited by G.C. Amstutz and A.J. Bemard, pp. 227-245, Springer-Verlag, New York, 1973.

Robb, J.M., and M.F. Kane, Structure of the Vema fracture zone from gravity and magnetic intensity profiles, J. Geophys. Res., 80 , 4441-4445, 1975.

Robinson, P.T., R.P. Von Herzen, A.C. Adamson, and Shipboard Scientific Party, Proc. Ocean Drill. Program Initial Rep., 118, 1989.

Roest, W.R., and B.J. Collette, The Fifteen Twenty fracture zone and the North American-South American plate boundary, J. Geol. Soc. London, 143, 833-843, 1986.

Searle, R., The active part of Charlie-Gibbs fracture zone: A study using sonar and other geophysical techniques, J. Geophys. Res., 86(B1), 243-262, 1981.

Simonian, K.O., and I.G. Gass, Arakapas fault belt, Cyprus: A fossil transform fault, Geol. Soc. Am. Bull., 89, 1220-1230, 1978.

Sleep, N.H., and S. Biehler, 1970. Topography and tectonics at the intersections of fracture zones with central rifts. J. Geophys. Res., 75, 2748-2752, 1970.

Thayer, T.P., Serpentinization considered as a constant-volume metasomatic process, Amer. Mineral., 51, 685-708, 1966.

Thompson, G., and W.G. Melson, The petrology of oceanic crust across fracture zones in the Allantic Ocean: Evidence of a new kind of sea floor spreading, J. Geol., 89, 526-538, 1972.

Van Andel, T.H., J.B. Corliss, and V.T. Bowen, The intersection between the Mid-Atlantic Ridge and the Vema fracture zone in the North Atlantic, J. Mar. Res., 25, 343-351, 1967.

Van Andel, T.H., R.P. Von Herzen, and J.D. Philips, The Vema fracture zone and the tectonics of transverse shear zones in oceanic crustal plates, Mar. Geophys. Res., 1, 261-283, 1971.

White, R.S., R.S. Detrick, M.C. Sinha, and M.H. Cormier, Anomalous seismic crustal structure of oceanic fracture zones. Geophys. J. $R$. Astron. Soc., 79, 779-798, 1984.

Williams, C.A., K.E. Louden, and S.J. Tanner, The westem intersection of Oceanographer fracture zone with the Mid-Atlantic Ridge, Mar. Geophys. Res., 6, 143-158, 1984.

Zelenov, K.K., Iron and manganese in eruptive material of the submarine volcano Bahu Vuhu (Indonesia) (in Russian), Dokl. Akad. Nauk. SSSR, 155, 1317-1320, 1964.

J.M. Auzende, IFREMER, Département Géosciences Marines, BP 70, 29280 Plouzané, France.

E. Bonatti, Lamont-Doherty Geological Observatory of Columbia University, Palisades, NY 10964.

M. Cannat and C. Mével, Laboratoire de Pétrologie Métamorphique, Université Pierre et Marie Curie, 5, Place Jussieu, 75230 Paris Cédex 05, France.

J. Honnorez, Institut de Géologie, Université Louis Pasteur, 1, rue Blessig, 67084 Strasbourg Cédex, France.

Y. Lagabrielle and V. Mamaloukas-Frangoulis, URA 1278 , Domaines Océaniques, Faculté des Sciences, 6, Avenue Le Gorgeu, 29287 Brest Cédex, France.

(Received February 13, 1991; revised February 18, 1992; accepted March 12, 1992.) 